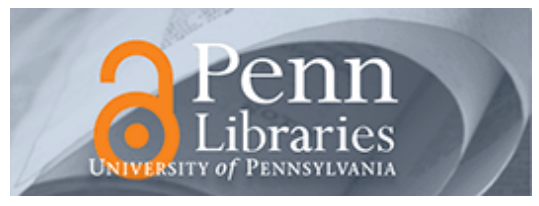

University of Pennsylvania

ScholarlyCommons

Management Papers

Wharton Faculty Research

$9-2013$

\title{
Keeping Up Appearances: Reputational Threat and Impression Management after Social Movement Boycotts
}

\author{
Mary-Hunter McDonnell \\ University of Pennsylvania \\ Brayden G. King
}

Follow this and additional works at: https://repository.upenn.edu/mgmt_papers

Part of the Advertising and Promotion Management Commons, Business Administration, Management, and Operations Commons, Business and Corporate Communications Commons, Business Intelligence Commons, Management Information Systems Commons, Management Sciences and Quantitative Methods Commons, Marketing Commons, Organizational Behavior and Theory Commons, and the Strategic Management Policy Commons

\section{Recommended Citation}

McDonnell, M., \& King, B. G. (2013). Keeping Up Appearances: Reputational Threat and Impression Management after Social Movement Boycotts. Administrative Science Quarterly, 58 (3), 387-419. http://dx.doi.org/10.1177/0001839213500032

This paper is posted at ScholarlyCommons. https://repository.upenn.edu/mgmt_papers/327

For more information, please contact repository@pobox.upenn.edu. 


\title{
Keeping Up Appearances: Reputational Threat and Impression Management after Social Movement Boycotts
}

\begin{abstract}
In this paper, we show that corporate targets' responses to social movements are a function of impression management to counteract perceived image threats created by movement tactics. An image threat occurs when an organization"s audiences or reference publics are given reason to doubt its reliability or claimed conformity to socially acceptable behaviors, norms and values. We examine organizational responses to image threats created by social movement boycotts. Consumer boycotts, while ostensibly trying to cause a decline in a firm's sales revenue and force them to change a policy or practice, have a pronounced negative impact on their targets' public images. Boycotts may elicit increased efforts by the firm to engage in positive impression management and to reinforce positive audience perceptions. We argue that firms frequently use corporate social actions as part of their image repertoire when dealing with the threat of boycotts. Corporate social actions are especially likely to be used by firms that have built their reputation around being a "virtuous" company. We draw on social movement theory and organizational theory to predict the conditions in which firms will respond to boycotts with increased levels of social action. We use a dataset of boycotts that were reported in major national newspapers from 1990 to 2005 to test our hypotheses.
\end{abstract}

\section{Keywords}

social movements, boycotts, media attention, impression management, prosocial claims, threat amplification, nonmarket strategies

\section{Disciplines}

Advertising and Promotion Management | Business Administration, Management, and Operations | Business and Corporate Communications | Business Intelligence | Management Information Systems | Management Sciences and Quantitative Methods | Marketing | Organizational Behavior and Theory | Strategic Management Policy 
Keeping Up Appearances: Increased Corporate Social Activity in Response to Social Movement Activism

\author{
Mary-Hunter Morris McDonnell \\ Kellogg School of Management \\ Northwestern University \\ 2001 Sheridan Rd.; Evanston, IL; 60201 \\ mary-morris@kellogg.northwestern.edu \\ (919) 923-2250 \\ Brayden King \\ Kellogg School of Management \\ Northwestern University \\ 2001 Sheridan Rd.; Evanston, IL; 60201 \\ b-king@kellogg.northwestern.edu
}

The authors would like to gratefully acknowledge Sarah Soule, Mayer Zald, Greta Hsu, Dave Whetten, Klaus Weber, and participants in seminars at Stanford University and the University of Michigan for comments on earlier drafts of this paper.

Total Word Count: 14635

Key Words: social movements, boycotts, organizations, corporate social responsibility 


\title{
Keeping Up Appearances:
}

\section{Increased Corporate Social Activity in Response to Social Movement Activism}

\begin{abstract}
$\underline{\text { Abstract }}$
In this paper, we show that corporate targets' responses to social movements are a function of impression management to counteract perceived image threats created by movement tactics. An image threat occurs when an organization's audiences or reference publics are given reason to doubt its reliability or claimed conformity to socially acceptable behaviors, norms and values. We examine organizational responses to image threats created by social movement boycotts. Consumer boycotts, while ostensibly trying to cause a decline in a firm's sales revenue and force them to change a policy or practice, have a pronounced negative impact on their targets' public images. Boycotts may elicit increased efforts by the firm to engage in positive impression management and to reinforce positive audience perceptions. We argue that firms frequently use corporate social actions as part of their image repertoire when dealing with the threat of boycotts. Corporate social actions are especially likely to be used by firms that have built their reputation around being a "virtuous" company. We draw on social movement theory and organizational theory to predict the conditions in which firms will respond to boycotts with increased levels of social action. We use a dataset of boycotts that were reported in major national newspapers from 1990 to 2005 to test our hypotheses.
\end{abstract}


A growing body of literature in organizational studies is dedicated to understanding the instigators of corporate social action, broadly defined as corporate activity that supersedes both legal mandates and the firm's narrow economic interests and is intended to promote "social benefits or mitigate social problems for constituencies external to the firm" (Marquis, Glynn \& Davis, 2007: 926). Some scholars maintain that corporations are internally motivated to engage in social action due to the insurance-like properties attendant to perceived social responsibility (Godfrey, 2005; Godfrey, Merrill \& Hanson, 2009) or its potential long-term performance advantages (Burt, 1983). A separate branch of research, however, links corporate social action to concerted pressure from external forces, such as social movements (Soule, 2009), local communities (Marquis, Glynn \& Davis, 2007) or other stakeholders (Baron 1999; 2001; Carroll, 1989; Clarkson, 1995; Freeman \& Gilbert, 1987). This perspective historically emphasizes coercive pressure as the primary mechanism driving stakeholder influence (Davis, Whitman and Zald 2008; Bartley 2003; 2007).

Given its focus on coercive mechanisms, it is unsurprising that research linking social movement activism to increased corporate social action has been dominated by issue-driven approaches that characterize social movement organizations as exercising considerable influence over their targets' responses (e.g., Lounsbury 2001; Raeburn 2004; Reid and Toffel, 2009). For example, Weber, Rao, and Thomas (2009) found that movement activists successfully penetrated German pharmaceutical firms to persuade them to cease manufacturing and distributing biotechnology products. Raeburn (2004) studied the likelihood that the corporations comprising the Fortune 1000 would extend their marriage benefits to domestic partners when pressured by LGBT activist organizations. Maxwell, Lyon, and Hackett (2000) suggest that numerous firms have 
adopted voluntary emissions controls in response to advocacy from the environmental movement.

But, in limiting its focus to mechanisms of direct influence and the incidence of direct concession to activist demands, this research stream has adopted a relatively narrow view of the impact of social movements. We know that firms often voluntarily engage in social actions that are substantively unrelated to movement demands. Yet, it is possible that even these social actions may be instigated by movement pressures, as for example, when Walmart makes community donations in the wake of protests against recent store openings (Ingram, Yue, and Rao 2010). We continue to lack a clear, empirically-supported theory that explains the link between social movement activity and more general increases in social action among organizational targets.

In this paper, we draw on impression management theory to proffer and test a dynamic, mechanisms-oriented theory of the link between social movement pressure and increased corporate social activity (e.g., Goffman, 1959; Elsbach and Sutton, 1992; Whetten and Mackey, 2002). Our ultimate goals are threefold: 1) to empirically test whether targeted organizations respond to social movement activism by increasing the frequency of visible social actions, 2) to proffer a theory of why this response occurs and the mechanisms by which it is moderated, and 3) to test the efficacy of increased social actions in ameliorating the threat of social movement activism. We suggest that the primary mechanism of influence wielded by mobilized movements is their ability to provoke an image threat in their organizational targets. An image threat occurs when an organization's audiences or reference publics are given reason to doubt its 
audience-specific commitments and expectations. The experience of an image threat encourages targets to be more heedful of the expectations of their external audiences. Targeted organizations may react to quell a movement-induced image threat by engaging in impression management, promulgating images that confirm their association with positively-valenced, identity-confirming activities that promote and protect favorable audience perceptions.

The use of corporate social actions to appease focal audiences is supported in research. For examples, Gray et al. (1995) suggest that disclosure of socially beneficial activities is one routine element of organizations' ongoing effort to enlist and retain the support of their primary audiences. Godfrey, Merrill, and Hansen (2009) argue that social actions can effectively promote goodwill from target audiences when organizations are facing a negative event, such as legal or regulatory trouble. In line with this past research, we suggest that increased social actions communicated in the face of an image threat represents an organization's efforts to manage the perceptions held by its internal and external audiences - namely, its identity and reputation - by diluting the salience of the discrepant information promulgated by the movement activists, providing identity-confirming information to reduce identity/image incongruence, and issuing confirming information to protect the organization's reputation among target audiences and opinion leaders. Thus, post-threat increases in social action operate as positivelydistinguishing image claims that buffer an organization's image by diluting, rather than necessarily refuting, the negatively-distinguishing claims waged by activists.

In addition to proffering the image threat as a primary mechanism linking social movement activism to increased frequency of social actions, we also seek to theoretically account for 
variance in organizations' responses to external activism. Specifically, we argue that the extent to which an image threat will provoke increased social action is moderated at both the social- and firm-level. First, at the social level, an organization's response to an external attack depends on its current social situation, namely, i) its reputation, or the way that the organization is perceived by its target audience, and ii) the extent to which the organization's reputation is founded on previous communications that social actions are integral to the firm's identity. Second, at the firm-level, the likelihood that an organization will attend to and act to ameliorate an image threat depends on the perceived viability of the activists' threat, namely i) the salience of the threat posed by the movement's activities, and ii) the perceived vulnerability of the organization's reputation.

The final goal of this paper is to determine whether increases in social action are an effective means to quell an extra-institutional image attack. Because we are arguing that intensifying social actions reduces the salience of threatening images and helps to maintain the support of an organization's focal audiences, we expect post-attack increases in social actions to be associated with a lower incidence of long term reputational damage for the organizational targets of social movement attacks.

We empirically test our theoretical predictions using a sample of consumer boycotts. Boycotts are a coercive social movement tactic, favored by upwardly mobile members of marginalized groups (Gardberg and Newburry 2010), that are employed in an effort to compel a targeted organization to change offensive behavior. Though boycotts ostensibly operate to disrupt an organization's material performance by slowing demand for its products or services, recent 
scholarship questions whether many boycotts are effective in constraining their targets' resources in this way (Vogel 2005; King 2008). Consumers are slow to change their behavior even when they support a boycott's ideals (Miller and Sturdivant 1977). In a recent paper, King (2008) postulated that the "most critical mechanism" shaping a boycott's influence is boycotters' ability to threaten their target's public image and harm its reputation: to provoke an image threat. To assess our theoretical propositions regarding the link between social movement activity and targets' social action disclosures, we examine the change in the number of socially-oriented activities that firms disclose via press releases in the six months after an announcement that the firm is being boycotted. Following the preponderance of literature in this area, corporate social actions are here defined to include all voluntary corporate actions extending beyond the mere transactional interests of the firm that are designed to provide social benefits or address the social problems of a firm's external constituencies (e.g., Aguilera, Rupp, Williams and Ganapathi 2007; Davis 1973; Waddock 2004; Mackey, Mackey and Barney 2007; Wood 1991a,b; Wood and Jones 1995).

Our chosen context is ripe for an in-depth inquiry into generalized social action responses to boycotts. Both boycotters and targeted firms rely on media outlets that allow them to capture the attention of and potentially persuade a wide array of audiences or reference publics (Lipsky, 1968). Given boycotters' implicit reliance on the media, the press release is an especially appropriate venue for firms wishing to combat any unfavorable information boycotters are issuing. Press releases can be posted in the same outlets that broadcast the activities of movement activists, allowing a company to communicate with the very same reference publics whose support the movement activists hope to enlist. Also, press releases can be issued on the 
fly, providing companies with a quick and flexible means to combat the boycotters' threat. These characteristics make the press release a more suitable venue for ameliorating the threat of a boycott than other popular social action disclosure venues, such as annual reports or corporate websites (e.g., Holder-Webb et al. 2009). Finally, press releases allow an organization to actively communicate messages that defend its image from activists' vilifying accusations without incidentally legitimizing the movement by publicly recognizing the boycott's existence or directly addressing the activists' claims.

We offer several theoretical contributions to organizational theory and the study of social movements. First, by developing a more dynamic model of the link between external activism and internal corporate social activity, we answer the call from management researchers for more research on corporate social activity that extends beyond the search for its relationship to economic performance (e.g., Walsh, Weber, \& Margolis, 2003). By focusing on the role played by the image threat in mediating boycotts' indirect effects on targets' general levels of social action, we contribute to an elucidation of the image threat as a mechanism undergirding social movements' tactical influence, contributing to the search for mechanisms-oriented accounts of movement phenomena (McAdam, Tarrow, and Tilly, 2001). Further, we show that firms' proclivity to engage in impression management - akin to an individual's presentation of self (Goffman 1959) - explains variation in firm responses to movement-induced image threats. Thus, our theory supplements work on impression management and "stigma management" (e.g., Elsbach and Kramer, 1996; Rivera, 2008) by casting corporate social actions as one mechanism employed by firms working to actively resolve threats to their image and identity. 
Finally, our study answers the call for more research on the consequences of social movement activity (Giugni 1998; Soule et al. 1999; Giugni, McAdam and Tilly 1999; Earl 2000). Whereas outcome-oriented social movement research has focused predominantly on targets' direct responses to a movement's demands (e.g., Rojas 2006; Bartley 2007; King 2008; Weber, Rao and Thomas 2009), our study delves into the less explored terrain of movements' potential indirect and unintended consequences (Deng, 1997; Cress and Snow, 2000). Scholars studying the impact of movements on markets have found that movements often have diffuse, unanticipated consequences for the emergence of new institutional logics (Haveman, Rao, and Paruchuri 2007) or the mobilization of resources and identities that cultivate the formation of new markets and industries (Sine and Lee 2009; Hiatt, Sine and Tolbert 2009). We contribute to this body of research by extending what has generally been understood as the response repertoire of targeted organizations to include a general increase in firms" "virtuous" behaviors (Vogel 2005). Our research ultimately suggests that activism may lead to increases in sociallyadvantageous action within the marketplace even when activists are not successful in eliciting a direct policy response to their own valued issue.

\section{Corporate Social Action as an Impression Management Tool}

Theories about the organization's relationship to its broader institutional environment help us understand why an organization might respond to extra-institutional activism by taking additional social action. Organizations operate within a superordinate social system or institutional environment that shapes their internal commitments and core character and identity traits (e.g., Selznick 1957; Parsons 1960; Dowling and Pfeffer 1975; Whetten 2006). As actors within a larger social or institutional system, organizations rely on the approval of relevant 
others, or "target audiences," in order to obtain needed resources and survive (Meyer and Rowan 1977; Oliver 1991; 1997). The relevant audience is made up of both primary stakeholders (including the employees, shareholders and other internal actors who are directly affiliated with the firm) and secondary stakeholders (including regulators, media, and other opinion makers who can indirectly influence the firm's success) (Clarkson 1995).

As organizations engage with their particular audiences, they make commitments that synchronously inform the expectations of their audiences and contribute to the formation of a unique organizational identity or character (Selznick 1957; Love and Kraatz 2009; King, Felin, and Whetten 2010). Because each organization relies on the support of target audiences to survive, it must heedfully cultivate a favorable conception of itself to promote among key stakeholders. This conception becomes the firm's identity. We follow Whetten and Mackey's (2002) characterization of the organizational identity as "a set of categorical identity claims... in reference to a specified set of institutionally standardized social categories." At the population or field level, identity claims are nested within a larger categorical system of identity choices that affiliate organizations with particular organizational forms, audiences, and expectations (Hsu and Hannan 2005; Hannan, Polos, and Carroll 2007). At the firm-level, claims might arise and evolve organically or be purposefully cultivated, but they create the internal component of every organization's self-management project and sustain an ongoing conversation with the focal audiences who share the social space in which the organization is embedded.

Previous research on organizational identity suggests that much of its value derives from its usefulness as a source of differentiation (Dutton, Dukerich and Harquail 1994). An emphasis on 
the uniqueness of organizational identity is apparent in Selznick's (1957: pg. 139)

characterization of an organization's identity as an enduring "special character" that arises as the characteristics or activities of an organization became infused with value over time. Scott (1995), too, suggests that an organization's character or identity represents "a distinctive set of values" endorsed by the organization. Importantly, this suggests that organizations cannot all claim or identify with the same values. Attempts to make far-reaching claims that depart from one's core identity may even lead to audience sanctions and cause the organization to be devalued relative to its peers (Zuckerman 1999; Hsu 2006; Hsu, Hannan, and Koçak 2009).

An organization's image represents its efforts to communicate its identity claims to its audiences. This communication is motivated by the intent of organizational insiders to shape the external audiences' conception of the organization's core beliefs, values, and role in the social framework (Bernstein 1984). Again, our definition is consistent with that proffered by Whetten and Mackey (2002), who describe organizational image as "what organizational agents want their external stakeholders to understand is most central, enduring, and distinctive about their organization."

Although a company could theoretically emanate whatever identity claims it pleased, firms that hope to succeed must maintain a viable image of conformity and commitment to socially acceptable - or legitimate - behaviors, norms and values (Meyer and Rowan 1977; Scott, Ruef, Mendel and Caronna 2000; DiMaggio and Powell 1983; Dacin 1997; Dowling and Pfeffer 1975; King and Whetten 2008). Corporate social action represents one category of such socially calibrated identity claims. These initiatives span a wide array of socially supported topics including, for example, charitable disaster relief, environmental protection programs, promotion 
of education, initiatives furthering social justice and diversity, and support of the arts. When firms disseminate images of themselves participating in social actions, they are conveying evidence to their audience that furtherance of the social good is a part of their corporate identity, implying that the symbiotic role they play with society merits the audience's support. This aspect of corporate social action has prompted writers in business ethics to herald corporate social disclosures as a sort of institutional panacea for image management, allowing organizations "to emphasize what [they are] doing 'well' while downplaying what [they are] not." (Holder-Webb et al. 2009: pg. 501).

Evidence from Useem's (1984) interviews with high-powered members of the "inner circle" supports the proposition that social action disclosures are used to strategically construct a coalition of supportive target audiences. In one particularly telling example, a chief executive from a large U.S. manufacturing company claimed that arts sponsorship provided incremental benefits, as "over time you get a larger and larger audience that has a better opinion of you" (1984: 120). Useem's interviews also highlight the deliberateness with which corporations employ social actions to cultivate and manipulate a company's image among key audience members. In one interview, for example, a spokesperson at IBM stated that the company supported operas, ballets, and schools to "make[] sure that its corporate image is associated with something both creative and culturally laudable." (120). An Exxon representative, too, cited evidence from surveys to suggest that the company's support of cultural programs "improves [our] image among those who count" (120). 
One consequence of organizations' active image cultivation is that an organization's image can be threatened if image-discrepant information becomes available to its audiences. Such discrepant information might leak from within a firm, be disclosed by a regulator or monitor, disseminated by a rival, or proffered by social movement activists (King and Soule 2007; Rindova and Fombrun 1999; Price, Gioia and Corley 2008; Fombrun and Shanley 1990; Hsu and Hannan 2005; Whetten and Mackey 2002). Discrepant information disrupts an organization's effective impression management, as audience members and internal actors receiving discrepant information may come to doubt the firm's expressed image or espoused identity. For example, while Chemical Bank disseminated images of itself in 1990 touting its participation in a lowincome housing program, movement activists in the town of Yonkers demanded a boycott of the bank's services, publishing blatantly image-discrepant information claiming that the bank's official policies unfairly discriminated against low-income mortgage applicants.

Aside from evoking dissonance surrounding an organization's image, doubt introduced among organizational audiences may threaten the organization's reputation, a valuable intangible asset based on stakeholders' evaluative feedback “concerning the credibility of the organization's identity claims" (Whetten and Mackey 2002; Fombrun and Shanley 1990; Fombrun, 1996; Weigelt and Camerer 1988). In times when a firm's image is threatened, therefore, it is likely that organizations will respond to defend their image and protect their reputation by increasing the amount of positive identity claims they communicate to audiences. As we have argued that corporations use social actions as a routine tool in building audience support, we predict that firms facing an extra-institutional image threat will disclose more social actions as a defensive impression management tool. Therefore: 
Hypothesis 1: Firms that are boycotted will increase the amount of social actions disclosed in press releases in the six months following the announcement of the boycott.

\section{Explaining firm-level variance in the use of corporate social actions}

In light of the identity heterogeneity of organizations, we do not expect that responses to image threats will be uniform across organizations. Firms have unique sets of focal audiences, not all of which will expect a firm to respond to image threats in this way. Rather, the extent of a single firm's use of social actions in response to a threat depends on a combination of both social- and firm-level factors.

Corporate social action disclosures are examples of deliberately disseminated images that organizations use in attempting to communicate their unique identities to target audiences. Images are inherently affected by each organization's conception of itself - its identity - and the evaluative feedback it receives from audiences - its reputation. Therefore, differences in organizations' established identities and reputations may explain why some firms draw upon images of social actions to mitigate image threats.

Firm Identity and Image Repertoires

Organizations use images to communicate identity claims and amass support from target audiences. These images synchronously serve as a means of organizational expression and 
restraint. This is because identity claims function as both communications and commitments (Selznick 1957; Whetten 2006): any audience support garnered by using images that portray the organization as behaving in a certain way creates a future expectation that the company will continue to act in that same way.

Moreover, research on organizational identity has stressed the importance of identity stability, suggesting that inharmonious images can provoke harmful internal dissonance (Dutton, Dukerich and Harquail 1994; Gioia, Schultz, and Corley 2000). Dutton and Dukerich (1991: 520), for example, argue that "each individual's sense of self is tied in part to [the organization's] image," suggesting that image threats may be interpreted by individual actors within organizations as affronts to their own personal identity. Recent evidence suggests that this may be especially true for organizations that have cultivated an impression among audiences of their identification with social issues because these may be especially valued by internal actors. For example, Carmeli, Gilat and Waldmen (2007) find that the perceived social responsibility of an organization is positively associated with organizational identification among employees._Further, a survey conducted by Stanford Graduate School of Business found that top MBA students place significant weight on the social actions of potential employers; they reported being willing to accept a lower salary job in return for placement with a company that outperforms others in this dimension (Montgomery and Ramus 2008).

In communicating their identities to external audiences, we argue that organizations craft distinct image repertoires (Clemens 1997). An image repertoire, in its entirety, represents a complete set of the identity claims that an organization has made to its audiences. When managing image 
threats, organizations are likely to respond in predictable ways, drawing from this assembled repertoire of identity claims to confirm the impressions and reinforce commitments previously fostered among both internal and external audiences. Organizations actively working to quell an image threat should disseminate information that supports past identity claims. These communications dilute the salience of the image threat and reduce whatever uncertainty the threat has provoked among target audiences who are concerned with the veracity of the organization's previous identity claims.

In the modern marketplace, many companies have already made earnest efforts to build a positive reputation by incorporating social responsibility initiatives into their business operations (Scherer and Palazzo 2007) or participating in other philanthropic activities (Useem 1984). While social actions are already a part of most companies' image repertoires, it remains predominately discretionary. In fact, it is the voluntary nature of social actions that make them especially valuable impression management tools. If organizations have made social actions integral to their identity when communicating with target audiences in the past, they are likely to continue using social action when responding to an image threat. Hence:

Hypothesis 2: The amount of social action disclosed before a boycott (base corporate social action before a threat occurs) will be positively associated with the change in the number of social action disclosures after a boycott. 


\section{Firm Reputation}

Organizations vary in the extent to which they are successful in convincing their target audiences of the veracity of the identity claims that they make. Reputation reflects a type of collective feedback from the organization's constituent audiences relaying the current credibility of the organization's images (Fombrun and Shanley 1990; Whetten and Mackey 2002). In this way, reputation can be thought of as a measure of the success of organizational attempts to manage audience perceptions.

Companies that have maintained strong reputations over time enjoy relative stability in their audiences' perceptions. Audiences of these organizations develop higher levels of confidence in the veracity of the organization's image and are more likely to give the organization's claims the benefit of the doubt when presented with discrepant information (Coombs and Halladay 2006). This is supported by research on the 'halo effect,' which suggests that organizations with stable, high reputations tend to be more resilient in the face of crisis and less vulnerable to environmental threats (Bromley 1993; Fombrun 1996; Sine, Shane and Di Gregorio 2003). Positive reputations make organizations more resilient in the face of crisis, so that they are less likely to perceive the threat as posing a credible risk to their cultivated image. Therefore, organizations with positive reputations will have less need to actively engage in impression management following a boycott:

Hypothesis 3: A company's reputation before a boycott will be will be negatively associated with the change in the number of social actions disclosed after a boycott 
However, if audiences perceive that a firm is reputable because its previous commitments to social action, the firm may be even more committed to this path of socially responsible action when faced with an image threat. In cases like this, the firm's reputation may be founded on past commitments that lead audiences to expect future social action. ${ }^{1}$ The image threat causes a direct contradiction between the discrepant information offered by the activists and the widely-held perception of the organization's identity. This may trigger the firm to attempt to resolve that contradiction by emphasizing and magnifying positively-differentiating images used in the past (i.e., more social action). Ultimately, therefore, reputable firms are the most shameable if they have built their reputation using images that are directly impugned by the discrepant information presented by activists. Further, viewing reputations as a valuable intangible asset, organizations with high reputations have more to lose as the result of the image threat, which ought to make them more likely to take action to counteract the threat with identity-consistent behavior. Taken together, these considerations suggest that individual organizational responses to image threats are the result of a fundamental interaction between the identity claims the organization has made in the past and its reputation. Specifically, organizations that have high reputations and have built those reputations partly through social actions should be most likely to respond to an image threat by doing additional social actions:

Hypothesis 4: The number of social action disclosures before a boycott will positively moderate the effect of reputation on the change in the number of social actions disclosed after a boycott.

\footnotetext{
${ }^{1}$ Research has shown that social movements are more likely to target reputable firms because these are the leaders of their fields and the most likely to be emulated by others (Strang \& Soule, 1998; McAdam \& Scott, 2005; Rao, Morill \& Zald, 2000; Rojas, 2006; Bartley and Child, working paper).
} 
The promulgation of press releases to quell an image threat requires action at the organizational level. However, just as individuals, organizations have limited abilities to attend to and act on the multitude of information and issues available to them (Simon 1947). In order for an organization to function it must be selective in where and how it directs its attention. Organizational responses to image threats, therefore, depend on the level of organizational attention that the threat attracts (Ocasio 1997; King, 2008).

Action at the organizational level depends in part on the focus of individual actors within the organization and the characteristics of the situation in which the focused attention occurs (Ocasio 1997). While a firm may be aware of an image threat, its external audiences may not be paying attention and therefore the attempted attack should not appear very threatening. Regardless of whether a threatened organization would choose in the abstract to defend its image, an organization's actual response to a social movement threat depends on i) whether the threat captures the focus of the target organization, ii) whether the organization's audiences are aware of the threat, and iii) whether the organization's situation influences actors to recognize the discrepant information as a viable threat to its image.

We propose that salient images are more likely to capture the focus of organizational actors, but that organizational members are unlikely to elicit an organization to actively counteract image threats unless they perceive the organization's public image as vulnerable. 


\section{Salience of Discrepant Information}

Not all boycotts will generate equal responses from the target organizations. Indeed, a poorly orchestrated boycott might pass without organizational actors or their audiences having ever been aware of it at all. The greater the salience of the discrepant information disseminated by the boycotters, however, the greater likelihood that the targeted organization will attend to the image threat and take action to counter it. Accordingly, we expect that organizations are more likely to act against an image threat when it receives more public attention, thereby making the threat more salient in the minds of organizational decision-makers (Hoffman and Ocasio 2001; King 2008).

Media attention, in particular, may afford a viable external avenue to organizational attention. Media attention both increases the salience of the image threat and implicitly legitimates that threat by recognizing it as worthy of public interest (Koopmans and Olzak 2004). A social movement's tactical threat is largely mediated by its ability to use the media to broadcast grievances to a broad audience, thereby shaping public opinion and changing social norms and drawing those audiences into a public fight (Lipsky 1968; Oberschall 1973; Walgrave and Manssens 2000). King (2008), for example, demonstrated that boycotts are more successful in garnering concessions from their targets when they receive more media attention. Thus, the ancillary effects of media attention should increase the apparent importance of the discrepant image and make organizational actors more likely to focus their attention on it. Therefore:

Hypothesis 5: The amount of media attention received by a boycott will be positively associated with the change in the number of social actions disclosed after a boycott. 


\section{Recent Changes in Reputation}

Reputations, being collective assessments of a firm's attempts to manage audiences' perceptions, ought to be relatively stable unless significant new images or information are made available to organizational audiences. A recent change in reputation increases the likelihood that the organization is attending to its public image and perceptions among audiences. For example, if reputations have recently increased, this suggests that an organization is actively attending to the expectations of its audience, disseminating images or publicly acting in ways that cultivate a more favorable conception of its identity. Further, organizations with recently improved reputations are unlikely to take their reputations for granted, instead wanting to protect and maintain this newly won intangible resource. On the other hand, firms with recently damaged reputations are especially sensitive to the demands placed on them by stakeholder activists.

An organization that is actively attending to its reputation is more presently heedful of its impression among target audiences. If an image threat occurs in this situational context, it is more likely that the organization will notice and will take action to neutralize the threat. But, organizations have options in how to ameliorate a social movement threat. King (2008) found that companies that have experienced reputation declines immediately prior to a boycott are more likely to respond by conceding. These organizations may be more cognizant of their audience's growing inclination to distrust or disapprove of them and, therefore, inclined to work with activists to neutralize the image threat in the quickest way possible. Having suffered a recent demoralizing loss in reputational capital, they may also simply lack the resources or motivation needed to wage an expensive social campaign to defend their past identity claims. 
In contrast, companies that have recently experienced a significant gain in their organization's reputation are less likely to concede to activists. Because of concession's implicit recognition of the veracity of the activists' claims and to protect their newly acquired legitimacy, organizations that have recently experienced a reputational gain might instead be motivated to engage in impression management and deflect the public's attention to the activists' disparaging claims by offering confirming evidence that they deserve their current high reputations. Experiencing a reputational gain may embolden a firm to accentuate the positive aspects of its image in the face of an image threat.

Thus:

Hypothesis 6: Recent increases in reputation before a boycott should be positively associated with the change in the number of social actions disclosed after a boycott.

However, an organization's response to an image threat depends on both the salience of the threat and the situational context in which the threat occurs. Therefore, media attention may increase the likelihood of receiving the organizational actors' focus, but the response will be even more intense when paired with the situational element of having experienced recent reputational changes. High levels of media attention to a boycott might amplify the image threat and get the attention of organizational actors, but an organization is most likely to actively respond disclosing more social action if it is already attending to its reputation and inclined to protect its recent reputational gains: 
Hypothesis 7: The interaction of the change in reputation before a boycott and the media attention received by a boycott will be significantly positively associated with the change in the number of social actions disclosed after a boycott.

\section{The Efficacy of Social Actions to Quell an Image Attack}

An image attack presents discrepant images that may cause key audiences to question an organization's claimed conformity to institutionally endorsed norms and values. Thus, a particularly effective image threat may ultimately jeopardize an organization's reputation, or the extent to which audience members perceive the organization as a socially valuable and normatively appropriate entity.

We have argued throughout this paper that social actions may be used as an impression management tool by firms facing an activist-induced image threat. Corporate social actions offer firms a means to promulgate positively-valenced images that encourage audience support by confirming the organization's identity as socially oriented and institutionally appropriate. Thus, firms that react to an image threat by disclosing additional social actions should have a higher likelihood of perpetuating a positive perception among their target audiences. As a result, these firms should be less likely to suffer reputational damage as a result of the image threat. It follows that: 
Hypothesis 8: Boycotted firms that increase their social actions should be less likely to suffer reputational declines in the years following the boycott.

\section{Methods}

\section{Data and Dependent Variable}

To assess how boycotts affect the changes in the number of corporate social action disclosures, we collected information on all of the United States-based boycotts targeting publicly-traded companies that were covered by top national newspapers from 1990 to 2005. Following a strong tradition in social movement scholarship of using newspaper data to identify major movement events (e.g., McAdam and Su 2002; Earl, Soule, and McCarthy 2003; Earl et al. 2004; Van Dyke, Soule, and Taylor 2004), coders gathered data on boycott reports from five national newspapers: the New York Times, Washington Post, Wall Street Journal, Chicago Tribune, and Los Angeles Times. Using these five national newspapers limited the potential for regional bias. ${ }^{2}$ Research assistants searched the newspapers during the corresponding time period for the word "boycott" in the article's text using the Factiva, Proquest, and Lexis-Nexis databases. They then matched the boycott reports with company-specific data from COMPUSTAT (includes all financial controls). In total, the dataset includes 133 distinct boycotts involving 189 target companies. Because financial data were not available for some of these target firms, the regression below only reports 165 observations of boycotted firms.

\footnotetext{
${ }^{2}$ One potential problem with gathering data from newspaper reports is that the dataset censors out boycotts that were not salient enough to warrant national media coverage. While ideally we would include all boycott events, we are comfortable with our results knowing that any media attention effect we find would be a conservative estimate.
} 
To operationalize the dependent variable - a measure of changes in target firms' corporate social responsibility initiatives after the boycott is announced - we gathered additional information on the number of times each target company announced its involvement in a corporate social activity in the six months before and the six months after a boycott's announcement. To find the initiatives, we used the online database Factiva and searched PR Newswire and Business Wire for all social action-related press releases issued by each boycotted company. Identified initiatives span a wide array of topics including, for example, social justice and diversity initiatives, disaster relief, environmental protection programs, promotion of education, and support of the arts. We do not include items that were not sent out directly by the company or items that announce that the company has been given an award for its socially beneficial activities because the company itself did not necessarily control the timing of these types of releases. Thus, the resulting dataset of corporate social actions reflects only initiatives that were clearly and calculatedly sent out to the public by the target firm. Our search yielded a total of 1,302 distinct social action initiatives promulgated by targeted firms in the year surrounding the announcement of a boycott. The dependent variable - the change in corporate social responsibility after the boycott's announcement - was calculated by subtracting the number of initiatives in the six months before the boycott from the number in the six months after the boycott. This change variable ranged from -13 to 16 with a mean of 1.01 .

In order to test hypothesis 1 - that firms are more likely to disclose social action initiatives after boycott events - we gathered additional data on corporate social action among a set of matched firms from a comparable group of publicly-traded firms. Given that firm size is a good predictor of whether a firm is boycotted (King, 2008), we randomly matched three firms from a sample of 
the five-hundred largest publicly-traded firms (by asset value) with the boycott targets. This resulted in a total set of 508 matched firms. We then compared the difference in corporate social action disclosures in the six months before and after the boycott event date for both the targeted firm and its three randomly matched firms. The complete set of matched firms was also included in the first stage of a Heckman regression model that allowed us to account for potential selection bias in our sample of firms targeted by boycotts.

\section{Independent Variables}

To test hypotheses 2, we included a measure of the company's base level of corporate social activity (base CSA), which is a count of the number of social action press disclosures released by a company in the six months prior to the announcement of a boycott. In order to normalize the distribution of this variable - which was naturally skewed to the right - we transformed it in the regression model by taking its square root. To assess hypothesis 3, we coded each firm's reputation in the year prior the boycott using Fortune magazine's list of the "Top 100 Most Admired Companies" in the United States. This list is regularly employed in organizational scholarship as a reliable indicator of a company's overall reputation (McGuire, Sundgren, and Schneeweis 1988; Fombrun and Shanley 1990; Staw and Epstein 2000; Roberts and Dowling 2002; King 2008). These data serve as a proxy for overall audience assessments, being founded, in part, on surveys capturing the perceptions of executives of peer firms. The variable used in the model represents an ordinal transformation of the raw reputation scores. Companies not included in Fortune's ranking received a value of "0." A score of "1" was given to companies receiving a raw reputation score ranging from 1 to 5; companies with raw scores between 5.1 and 7.99 received a score of " 2 ." The highest value, "3," includes all companies that received a 
reputation score higher than an 8 . The grouping of the scores roughly corresponds to the quartiles of raw reputation score among firms in our sample. Hypothesis 4 is tested by the inclusion of an interaction variable of the product of the base number of social action disclosures and reputation variables. Hypothesis 8 is tested using a binary variable - reputation damagethat was coded " 1 " if a firm's Fortune reputation score decreased in the two years after the year it was boycotted, and " 0 " otherwise.

To test hypothesis 5, we include an independent variable -- level of media attention - that reflects a count of the number of newspaper articles that discuss a boycott in the six-month period following the announcement of a boycott. The newspapers searched for articles concerning the boycotts include The New York Times, Washington Post, Wall Street Journal, Chicago Tribune, and Los Angeles Times. We exclude all articles that deal with the initial announcement of the boycott and those dealing with a boycott concession. To evaluate hypothesis 6 we include a measure of reputation change. This variable was derived from the reputation score used to test hypothesis 3 . This variable indicates the difference in a company's reputation two years prior to the boycott and its reputation in the year of the boycott. Higher scores reflect positive changes in reputation. Because Fortune's admiration rankings are computed using a survey conducted in the year prior to the index's publishing year, this variable reflects a one-year lag and does not result from the actual boycott. To test hypothesis 7 we include an interaction variable of the product of the media attention and reputation change score. 


\section{Control Variables}

We include a number of control variables to account for variance explained by firm-level characteristics and situational features of the boycott. To control for a firm's general level of PR activity, we include a variable capturing the total number of non-social action related PR releases (Total Other PR) of each firm in the six months prior to a boycott. To correct for the skew in this variable, we took its square root. As a proxy for each firm's size, we control for the logged number of employees. We also control for each firm's market to book ratio as a general proxy for financial strength.

Given Waddock and Graves' (1997) popular business case for corporate social responsibility suggesting that the level of social action a company will engage in is mediated by the level of slack resources held by a company at any one time, we included a control for the firm's free cash flow which approximates the amount of the company's excess resources. This variable, collected using Standard and Poor's COMPUSTAT database, is calculated as the firm's depreciation value added to its operating income and divided by its total number of common shares. The use of a firm's cash flow operationalized in this way as a general indicator of slack is common in business literature (Davis and Stout 1992; King 2008; King and Soule 2007).

Because a target firm's industry may affect its general propensity to engage in corporate social responsibility initiatives (e.g., Chen and Bouvain 2009; Delmas and Toffel 2004; Marshall Cordano and Silverman 2005), we included dummy variables for a number of industries: Technology, Financial, Media and Health. We also included a dummy variable that reflects whether the target of a boycott was a subsidiary of a company instead of the mother company. 
Such boycotts might be expected to be gauged as less threatening to the parent company than a boycott waged against the parent company itself. Finally, we included dummy variables to control for common issues raised in the boycotts, including boycotts raising animal rights issues, safety issues, environmental concerns, labor issues, religiously-motivated issues, or claims of gender discrimination. ${ }^{3}$ Descriptive statistics for all dependent and independent variables are included in Table 1, below.

\section{[Insert Table 1 about Here]}

\section{Regression Model}

In the regression models testing hypotheses $2-7$, our dependent variable, change in the number of corporate social action disclosures, is normally distributed. Although the count variable from which it was created has a Poisson distribution, the difference between the number of initiatives does not have the same skewed distribution and is not truncated at zero. We therefore use a form of linear regression to estimate our results.

In order to account for the potential endogeneity of social action and the likelihood of being boycotted, we use a Heckman selection analysis in which the first stage model is a probit regression of the likelihood of being boycotted and the second stage model is an OLS regression of the change in the number of social action initiatives. The final stage includes a Heckman selection coefficient in the model to control for the probability that a company would be boycotted in the first place. We included the Fortune 500 matched sample in the first stage probit analysis. Following King (2008), we included two exogenous variables, the number of times that a firm was boycotted in the previous five years and the number of times that a firm's industry

\footnotetext{
${ }^{3}$ We included other issue dummies in models not shown but they did not improve the fit of the model.
} 
was boycotted in the previous five years, in the first stage analysis. Neither variable was correlated with the dependent variable in the second stage of the analysis, but were highly predictive of whether a firm became a boycott target. In this first stage of the regression, we also controlled for the total assets of each company, the square root of its base social action in the prior six months, and the square root of its total non-corporate social action PR activity in the prior six months.

To test hypothesis 8 , we employ a probit regression of all independent and control variables on the likelihood of suffering a decline in reputation in the two years after being targeted by boycotters.

\section{Results}

To test hypothesis 1, we first employed a paired t-test to examine whether our sample of boycotted firms significantly increased the number of social action disclosures in response to the announcement of a boycott. Among the 168 firms in our sample, the mean number of social action press releases in the six months before a boycott's announcement was 3.30 and the mean number of social action releases in the six months after was 4.31. This difference was significant at the .001 level. To make sure that these differences were due to the boycott itself rather than to exogenous factors accounting for general increases in social action across all firms during a certain time period, we next employed an unpaired t-test comparing the change in social action disclosures of boycotted firms with that of the randomly matched non-target firms. Boycotted firms averaged an increase of 1.01 releases in the six months after a boycott's announcement, whereas the randomly matched firms averaged an increase of only 0.17 disclosures. This 
difference was significant at the .001 level. This t-test confirms that the increase in disclosures was associated with a boycott event and was not caused by exogenous factors. Together, these two t-tests provide support for hypothesis 1 - that firms respond to boycotts by increasing their communicated corporate social action.

In addition to comparing the quantity of social action disclosures, we also engaged in a manual content analysis to code for various dimensions of the disclosures' qualities. We then compared the disclosures of boycotted companies before and after the boycott's announcement. Comparing the before and after number of disclosures on a number of dimensions, we found no significant differences in their length, the likelihood of donating money, the amount of donated money, or the likelihood of partnering with other organizations. We expect that the apparent stability in the qualities of corporate social action disclosures is largely due to the routinization of the task of preparing press releases within the specialized public relations wing of most large companies. Thus, the utilization of social actions to palliate an image threat seems to rest primarily on the quantity of disclosures, rather than their content.

Table 2 shows the results of the first-stage probit model. The first-stage results replicate King's (2008) findings that activists are more likely to target firms that have been boycotted in the past five years or that belong to industries that have been frequently targeted by boycotts in the past five years. Contrary to King (2008), we find that firm size is negatively associated with the likelihood that it will be boycotted when controlling for the past number of social action disclosures. This contradictory finding suggests that the effect of firm size on the likelihood of being boycotted is mediated by a firm's level of social activity. Activists appear to target firms 
that are actively cultivating an image of social responsibility. Activists may choose to target such companies because this image can be easily contradicted with discrepant information, affording a proximate opportunity to damage the company's relationship with its audiences and create an image crisis. This finding also runs contrary to Baron's (2001) proposition that social action should buffer an organization from being targeted by extra-institutional attacks.

\section{[Insert Table 2 about Here]}

The regression results of the models testing hypotheses $2-7$ are reported in Table 3 below. Model 1 shows the main effects of our independent variables. Without including the interaction effects, the results in Model 1 do not provide evidence of a statistically significant relationship between corporate social action before a boycott and the change after a boycott, nor is there a significant relationship between a firm's reputation and change in the number of disclsures. However, when controlling for the interaction effect between base CSA and reputation included in Models 2 and 4, the effects of both reputation and base CSA become negative and significant. These findings directly refute Hypothesis 2, while supporting Hypotheses 3 and 4. The findings indicate that the main effects of reputation and base CSA are conditional on the interaction between the two variables.

The negative main effect of base CSA may reflect a capacity problem facing firms that do a lot of social action. Firms that are already expending significant resources on social action may find it difficult to increase their disclosure activity when threatened. The effect may not be due to a lack of motivation, but rather a lack of capacity to do additional social action. Consistent with 
Hypothesis 4, however, we find that the effect of reputation becomes more positive among firms that have disclosed much social action in the past. This finding suggests that the base CSA positively moderates the effect of reputation on changes in the number of disclosures.

\section{[Insert Table 3 about Here]}

For clarity, we've graphed the predicted change in social action disclosures depending on the reputation of the firm and base CSA in Figure 2. The figure shows that reputation is negatively associated with change in the number of disclosures for firms that had few social action-related disclosures in the six months prior to a boycott, but reputation becomes positively correlated with the change in disclosures for firms at higher levels of pre-boycott social action disclosures. The findings suggest that firms that were above average (mean $=3.3$ ) in their use of social action and above average in their reputation (mean $=1.4$ ) were especially likely to increase their use of social action following a boycott. Firms that have strong positive reputation without actively engaging in many social action-related disclosures will rely on their reputation to buffer their image from the negative consequences of the boycott, but as the level of base CSA increases that is, as the expressed past commitment to social action increases - firms with strong reputations are compelled to respond by disclosing even more social action after a boycott. Such a finding supports our expectation that firms respond to image threats using social action when it is associated with positive reputation. The audiences of these firms have come to value social action as core to their identities. The past commitments to social action make it an integral tool in the firm's image repertoire. And these organizations, with valuable intangible assets resting on 
their image of virtuosity, are especially motivated to go to great lengths to protect their image of virtuosity when it is challenged.

\section{[Insert Figure 2 about Here]}

In addition, Model 1 demonstrates a significant positive effect of a boycott's media attention on the change in its target's disclosure activity after a boycott. The main effect of the target's change in reputation is not independently significantly associated with the change in corporate social responsibility activity. However, when controlling for the interaction between media attention and change in reputation in Models 3 and 4, both media attention and reputation have significant main effects. Thus, our results provide robust support for Hypothesis 5 and some support for Hypothesis 6. The interaction between media attention and reputation is also significant and positively associated with the change in social action disclosures after a boycott. This finding is consistent with the expectation that organizational response by increased social action is predicated on both the focus of organizational actors and the elements of the situation in which the focus takes place, providing robust support for Hypothesis 7. This interaction is depicted in Figure 3.

\section{[Insert Figure 3 about Here]}

As can be seen in Figure 3, the predicted change in social action disclosures increases more with each successive newspaper report about the boycott for firms that had recent reputation increases. Firms one standard deviation above the reputation change mean have much higher 
rates of post-boycott changes in social action than firms at the mean or one standard deviation below the mean, and this gap increases at higher levels of media attention. To the extent that media attention captures the salience of the image threat, the result implies that firms experiencing recent reputation gains are much more likely to take proactive solutions to image threats, amplifying the distinguishing characteristics of the company that merit its newly won esteemed position. The finding is especially interesting when compared to King's (2008) analysis, which showed that firms were more likely to concede to boycotts when experiencing a reputation decline. Taken together, the results indicate that firms may respond proactively, seeking to emphasize the company's inherent virtue, after a recent reputation increase; however, after recent reputation declines, the response to an image threat is more reactive. Firms in a reputation loss condition may simply find it less troublesome for their image to give in to the demands of boycotters than fight the image threat with contradictory, positively enhancing images.

In models not shown here, we also controlled for whether or not firms conceded to the boycotters' demands, but we found no significant relationship between concessions and increased social action. Further, the base correlation between direct concession and the change in social action after a threat is less than 0.01. This suggests that direct and indirect responses are not mutually exclusive, but rather, direct concessions to social movement activists and the indirect image work needed to maintain favorable audience impressions may be supplementary responses used to ameliorate an extra-institutional image threat. 
The regression results for the model predicting the likelihood of suffering a reputation decline after being boycotted are reported in Table 4. Hypothesis 8 - that firms that increase their CSA disclosures in the wake of a boycott will be less likely to suffer reputational damage after the boycott - is supported. We find a significant negative relationship between the change in the number of corporate social activities disclosed after a boycott and the likelihood of a reputational decline in the two years following the boycott. ${ }^{4}$ Interestingly, we find that firms are more likely to suffer reputational damage when the boycott is waged over an environmental issue, suggesting that these issues may carry more stigmatic weight with key stakeholders. We also find a significant positive relationship between media attention and reputation damage, suggesting that boycotts that receive more media attention are more likely to do long term reputational damage to their targets. This model suggests that increased corporate social activity may indeed help to quell the image threat induced by external activists and lessen the likelihood of long term reputational damage.

\section{[Insert Table 4 About Here]}

\section{Discussion and Conclusion}

Several recent contributions to the study of social movements have documented the potential for well-orchestrated social movements to coerce corporations into making policy changes in line with their demands. For example, a substantial literature has accumulated demonstrating the consequences of movements for policy change (e.g., McCammon et al. 2001; Soule and Olzak 2004; Soule and King 2006), cultural and identity transformation (e.g., Armstrong 2002;

\footnotetext{
${ }^{4}$ In supplementary analysis we do not find that responding to a boycott with increased social action increases the likelihood of a reputational gain. In this respect, ameliorating the image threat with social action disclosures merely serves to buffer the firm from potential negative reputational feedback.
} 
Bernstein 2005), the creation of new markets (e.g., Weber, Heinze, and De Soucey 2008; Sine and Lee 2009) and organizational policy changes (e.g., Weber et al. 2009; Schurman and Munro 2009). However, in this paper we suggest that social movements may additionally influence their organizational targets in a more indirect way, by provoking an image threat that prompts targets to engage in impression management meant to appeal to their general audiences. We show that movement targets' use of social disclosures is frequently a response to social movements because it reinforces positive audience expectations and buffers the organization from the potential image threat set in motion by the movement. When organizations have built a positive reputation by fostering an image of virtuosity through the active employment of social initiatives, they will respond to image threats by doing even more social activity. Thus, promulgated images that depict an organization unfavorably may spur reputable firms to go to extraordinary lengths to demonstrate their virtuosity. They accentuate those identity characteristics that favorably distinguish them. When firms do not have a history of "doing good" -- or when that history has not crystallized into a positive reputation -- they are less likely to respond to image threats with increased social activity. Our findings, thus, indicate a clear causal mechanism between intensified efforts by movements to target for-profit firms and increased efforts in the corporate sphere to appear socially responsible (Soule 2009).

Importantly, although we argue that corporate social activity is useful as an impression management tool, the social activities of most firms extend beyond purely symbolic 'fluff.' Social activities often impose significant costs and demand long-term commitments from the companies undertaking them. Moreover, as we have argued throughout the paper, social disclosures create audience expectations that the organization will continue to support social 
issues, which may impose long-term costs and commitments on the firm. Although these commitments are costly for the firm, increased corporate social activities carry the potential to engender substantial benefits for society. Our findings further indicate that increased social activity has practical effects on the organization's long term stakeholder relationships, as it is positively associated with the preservation of an organization's reputation after an image attack.

Our study contributes to social movements literature by enriching our understanding of strategic interaction of movement actors and the organizations they seek to influence, as movements and targets vie over the socio-political legitimacy of corporate behavior (McAdam 1983; Ingram, Rao and Yue, 2010). Specifically, our findings highlight targets' tendency to engage in impression management as a general mechanism that explains how movements influence their organizational targets. While many studies have looked at aggregate uses of tactics within one movement (e.g., Olzak and Uhrig 2001), our study focuses on a single tactic - the boycott - used in a cross-section of social movements. Past research on boycotts has emphasized their role in disrupting sales and organizational routines (e.g., Friedman 1985; Pruitt and Friedman 1986; Pruitt, Wei and White 1988). This depiction of boycotts is congruent with a more general view of movement tactics as functioning through a disruptive mechanism (Rojas 2006), although it provides an important nuance to the explanation. Movement tactics are often thought to be effective because they disrupt organizational routines or stability, making it difficult for elites to reproduce their social positions and political power (Piven and Cloward 1977; Skrentny 2006) or increasing the costs of carrying out normal business (Luders 2006). Our conceptualization suggests that movement effectiveness is more complex and situational. Rather than focusing on routines or elite's control over resources, we suggest that scholars should pay more attention to 
the affective qualities of collective actors (e.g., identity and reputation), the relationship of movement targets to their core audiences, and the situational elements that make some movement tactics more salient or threatening.

Our findings support the idea that organizational targets are complex structures with actor-like qualities. Organizations are likely to act on past commitments made to their various audiences and aspire to meet the expectations that valued audiences create for them based on those commitments. Through this ongoing interaction between organization and audience, an organizational identity develops that has long-term impact on the behavior of the organization. This paper assesses one implication of this "presentation of self" (Goffman 1959) - the systematic responses of organizations facing an external image threat. The past commitments of an organization condition the kinds of responses that an organizational target will have to a movement threat. Movement scholars should continue to explore the ways in which movements create image threats, forcing their targets to respond by engaging in impression management with their audiences. We suggest that this ongoing project of impression management is a sorely ignored aspect of movement-target interaction. Impression management should be relevant in every context in which movements offer challenges to elites, including the policymaking domain where elites' identities and reputations are consequential to personal and collective efficacy. Seen in this light, social movements are a kind of reputational entrepreneur who actively cultivate and threaten to undermine targets' images (Fine 1996).

The findings also point to the importance of situational effects on target responses to image threats created by social movements. As actors actively engaged in impression management, 
organizational targets are most likely to respond to attempted character attacks when the threat is perceived as real and when emboldened due to recent positive returns to their reputation. Our findings suggest, then, that increased corporate social activity may be seen as the most viable response to image threat when the organization is in a good position to defend its character. When a firm's reputation is rising and a perceived threat is made against its character, the firm is simply better positioned to defend its virtue; whereas when a firm has recently suffered reputational declines, it may be in a weak defensive position. Other responsive tactics might be better suited at that point (e.g., conceding to the boycotters' demands) and the firm may opt to simply make the threat go away altogether rather than fight the negative perceptions mounted by the agitators. Additionally, if the attack is not seen as very threatening (i.e., the boycott lacks media attention), then the firm sees little need to respond in any way (King 2008). These studies, together, suggest that social movement scholars ought to explore further the connection between the situational context of an image threat and the various responses that movement targets might have to that threat. Clearly, movements may respond in a variety of ways to a boycott or any other movement tactic. Future research ought to explore heterogeneity in target responses.

In addition to making contributions to social movement theory, the paper contributes to organizational theory by demonstrating that firm's reactions are indeed embedded in the expectations held by audiences, but these expectations may vary from firm to firm, depending on the firm-specific commitments that the organization has made. Not all firms engage equally in social activity because they have either never done it before or because they do not have a reputation linked to it. The findings, therefore, challenge theorists to consider more seriously how the histories and identity characteristics of organizations matter in their interactions with the 
broader environment. Organizational responses to the environment, we surmise, may be highly moderated by unique firm-level commitments and perceptions. Firms respond differently to threats in their environment, depending on their past commitments and audience expectations. In this way, our paper blends together assumptions from the new and old institutionalisms (Selznick 1996).

The analysis also suggests that social movement scholars ought to focus more on the ways in which both activists and their targets are engaged in ongoing impression management activities. The analysis points to the sensitivity of movement targets to image threats created by disruptive movement activities. Social movement scholars should, in general, pay more attention to these cultural, symbolic outcomes of movement activity. While much social movement research focuses on the material effects of movement tactics, the symbolic effects may be even more real and significant, especially when one considers movements' influence over markets (King and Pearce 2010), which are inherently grounded in symbolic understandings about what is valuable and appropriate. Inasmuch as reputation is one of those valued symbols that organizations embrace, the consequences of movement tactics may hinge on their ability to effectively disrupt the images firms communicate to their audiences and threaten their established reputations. 
Figure 1: Issues most highly represented in corporate boycotts, 19902005*

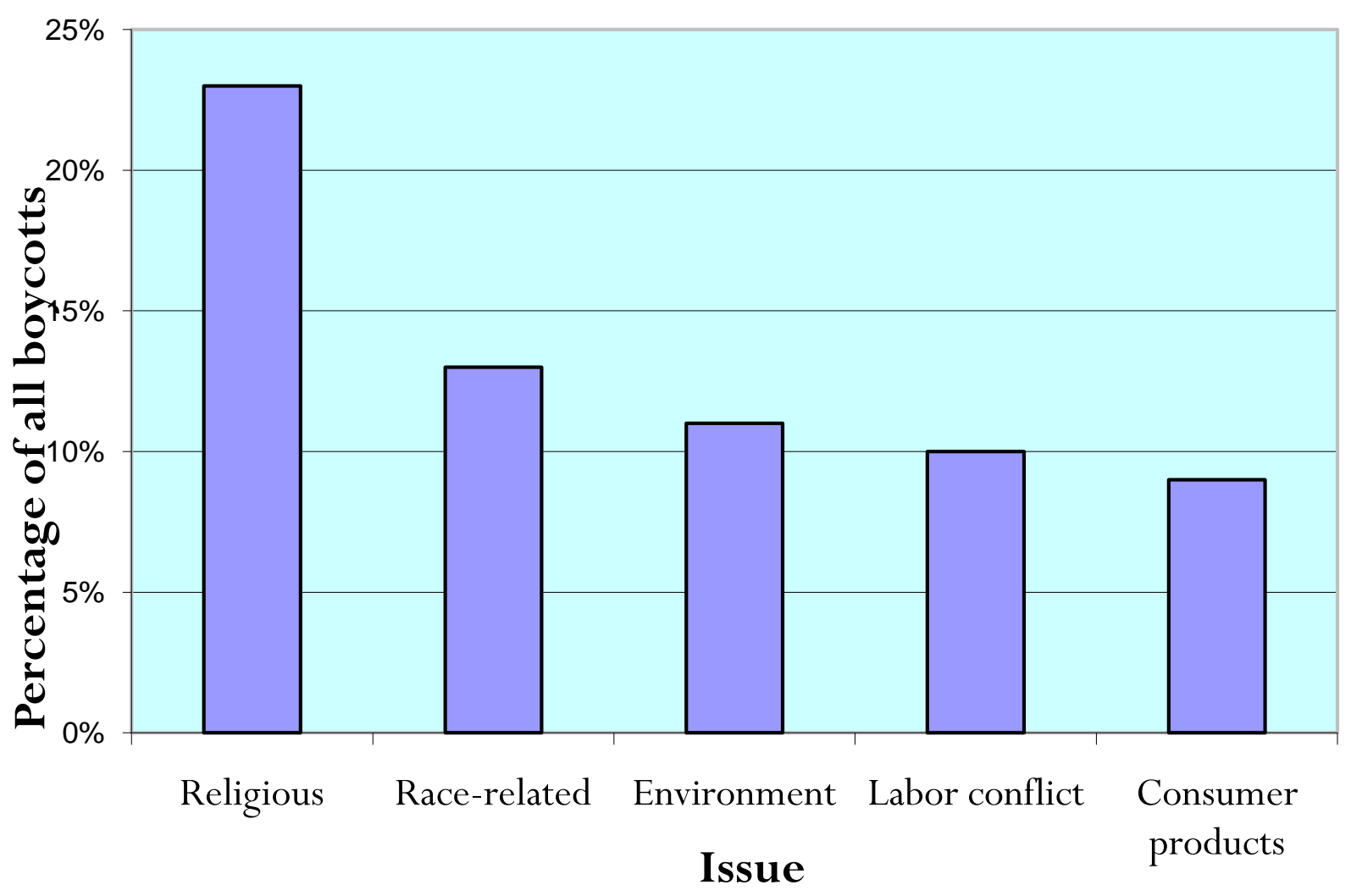

*Boycotts reported in the New York Times, Washington Post, Wall Street Journal, Chicago Tribune, and Los Angeles Times. 
Figure 2

Graph of the Interaction Effect between the Effect of Reputation and Base CSR Activity on the Change in Corporate Social Activity after a Boycott

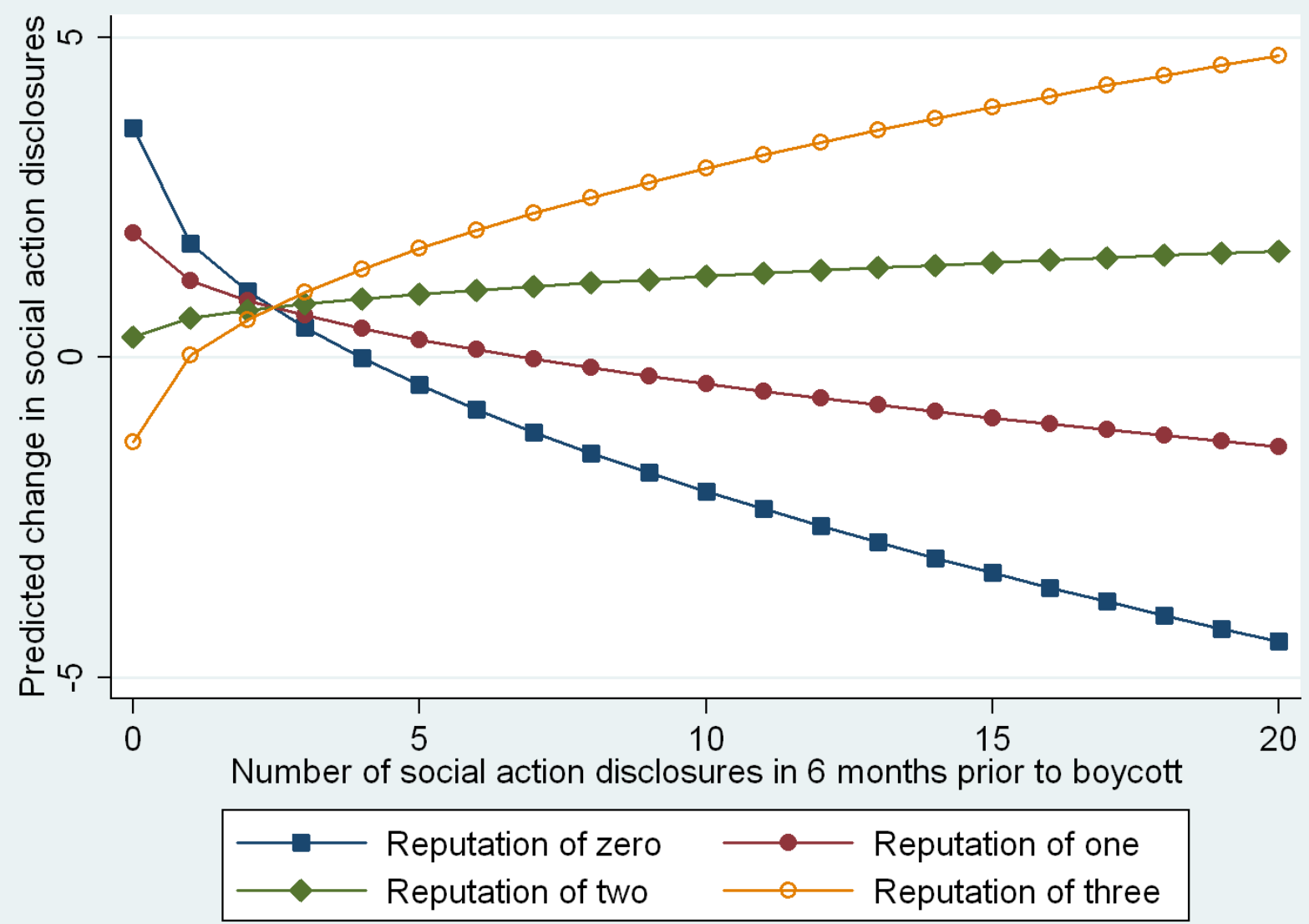




\section{Figure 3}

Graph of the Interaction Effect between the Effect of Media Attention and Reputation Change on the Change in Corporate Social Activity after a Boycott

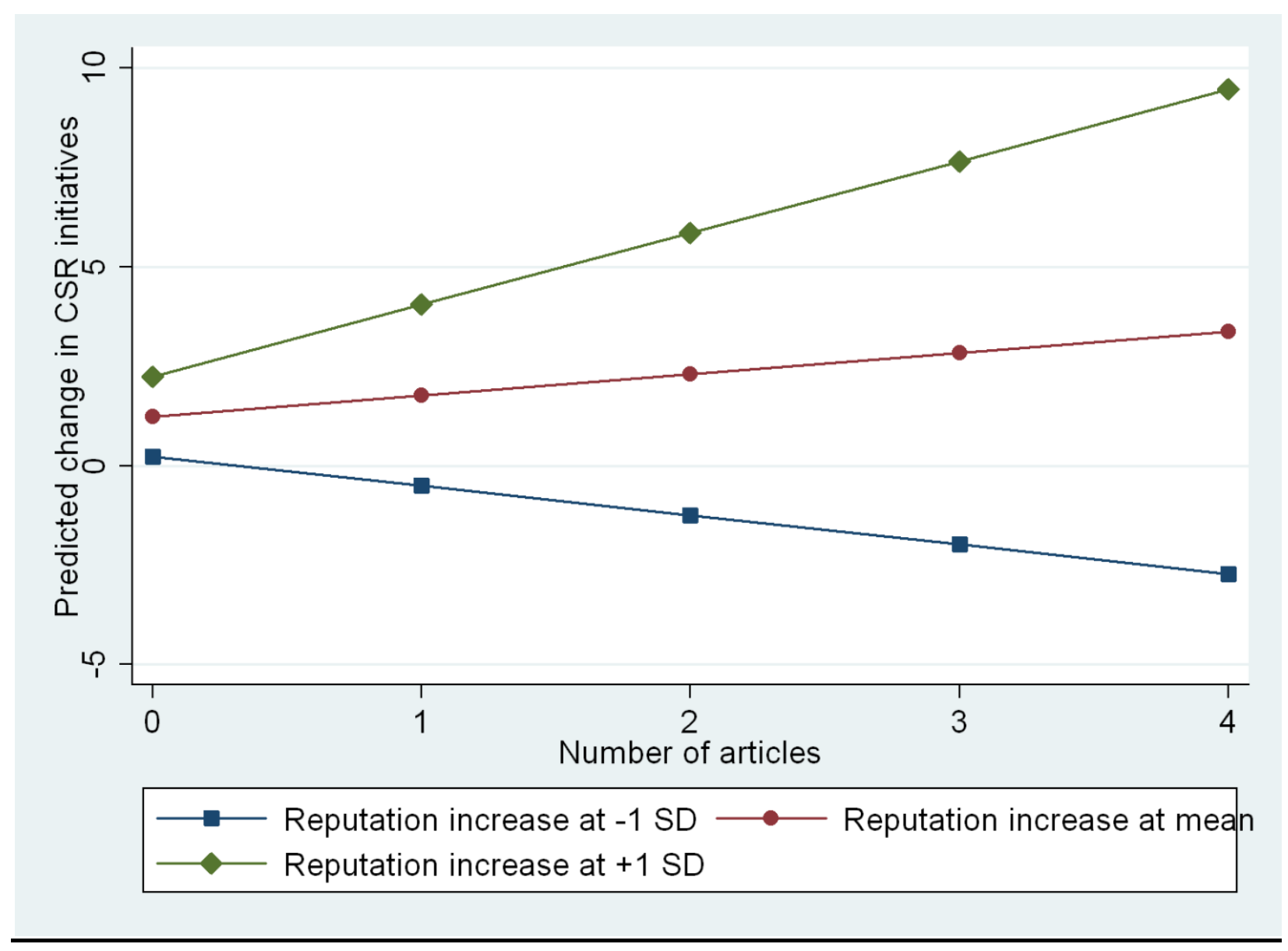


Table 1

Descriptive Statistics and Correlation Matrix of Independent and Dependent Variables

\begin{tabular}{|c|c|c|c|c|c|c|c|c|c|}
\hline Variable & Mean & S.D. & 1 & 2 & 3 & 4 & 5 & 6 & 7 \\
\hline 1. Change & 1.024 & 3.73 & 1.0000 & & & & & & \\
\hline 2. Reputation| & 1.370 & 1.14 & $0.1535 *$ & 1.0000 & & & & & \\
\hline 3. Base CSA & 1.664 & 1.02 & -0.0068 & $0.2363 *$ & 1.0000 & & & & \\
\hline 4. RepChange & 0.303 & 0.93 & -0.0041 & $0.3788 *$ & 0.0257 & 1.0000 & & & \\
\hline 5. Media Att.। & -0.436 & 1.63 & 0.0655 & 0.1457 & 0.0716 & 0.0069 & 1.0000 & & \\
\hline 6. Total PR । & 5.879 & 4.97 & 0.0616 & $0.1755^{\star}$ & $0.4013 *$ & 0.0194 & -0.0324 & 1.0000 & \\
\hline 7. Subsidiaryl & 0.363 & 0.48 & $-0.1748 *$ & $-0.2015 *$ & -0.0519 & 0.0302 & 0.0105 & -0.0857 & 1.0000 \\
\hline 8. Ind. Tech & 0.727 & 0.26 & -0.1322 & $0.2395 *$ & $0.2890 *$ & 0.0612 & 0.0747 & $0.4755^{\star}$ & 0.0716 \\
\hline 9. Ind. Heal. & 0.024 & 0.15 & 0.0422 & -0.0471 & -0.0566 & -0.0933 & -0.0305 & 0.0384 & -0.0403 \\
\hline 10. Ind. Fina.। & 0.103 & 0.30 & -0.0162 & $0.1814 *$ & 0.0697 & 0.0345 & 0.0694 & 0.1150 & 0.0497 \\
\hline 11. Ind. Ener & 0.109 & 0.31 & -0.0319 & 0.0469 & -0.1304 & -0.0075 & -0.0141 & -0.1403 & $-0.2286 *$ \\
\hline 12. Ind. Medial & 0.224 & 0.42 & 0.0303 & 0.1158 & -0.0460 & 0.0938 & $0.1787 *$ & -0.0029 & $0.3597 *$ \\
\hline 13.Environ & 0.109 & 0.31 & $0.2241 *$ & 0.0132 & 0.0875 & $-0.1545 *$ & -0.1095 & 0.0544 & -0.1491 \\
\hline 14.Animals & 0.024 & 0.15 & -0.1275 & -0.0471 & 0.0826 & 0.0771 & 0.1631 & 0.0239 & 0.0403 \\
\hline 15.Safety & 0.006 & 0.08 & 0.0629 & 0.0443 & -0.0336 & 0.1437 & $0.2607 *$ & 0.0016 & -0.0599 \\
\hline 16. Labor & 0.109 & 0.31 & 0.1092 & 0.0973 & $0.2723 *$ & -0.00495 & -0.0021 & 0.0562 & -0.0696 \\
\hline 17.Religious & 0.224 & 0.42 & -0.0743 & -0.0139 & -0.1031 & 0.0418 & 0.1103 & 0.0109 & 0.0808 \\
\hline 18. Gender & 0.036 & 0.19 & 0.0239 & 0.0152 & -0.0422 & $0.1598 *$ & 0.0931 & 0.0414 & -0.0385 \\
\hline 19. LogEmploy & 4.139 & 1.63 & 0.0758 & $0.3320 *$ & $0.3598 *$ & 0.0486 & 0.1193 & 0.1085 & 0.0592 \\
\hline 20. Cash & 16.751 & 152.2 & 0 . & 0.1136 & -0.0706 & -0.0234 & -0.0263 & -0.0155 & -0.0627 \\
\hline 21.Mark.2Book| & 3.103 & 10.69 & 0.0347 & 0.1116 & -0.0106 & 0.0061 & 0.0756 & 0.0463 & 0.0955 \\
\hline
\end{tabular}

\begin{tabular}{|c|c|c|c|c|c|c|c|c|c|}
\hline I & 8 & 9 & & 0 & 11 & 12 & 13 & 14 & 15 \\
\hline $\begin{array}{l}\text { 8. Ind. Tech. } \\
\text { 9. Ind. Heal. } \\
\text { 10. Ind. Fina. } \\
\text { 11. Ind. Ener } \\
\text { 12. Ind. Media| } \\
\text { 13. Environ } \\
\text { 14. Animals } \\
\text { 15. Safety } \\
\text { 16. Labor } \\
\text { 17. Religious } \\
\text { 18. Gender } \\
\text { 19. Log Employ } \\
\text { 20. Cash } \\
\text { 21. Mark.2Book| }\end{array}$ & $\begin{array}{c}1.0000 \\
-0.0433 \\
0.2776 \star \\
-0.0961 \\
0.1315 \\
-0.0214 \\
-0.0433 \\
-0.0215 \\
0.0534 \\
-0.0395 \\
0.0578 \\
0.1627 \star \\
-0.0236 \\
0.0717\end{array}$ & $\begin{array}{r}1.0000 \\
-0.0541 \\
-0.0541 \\
-0.0830 \\
-0.0541 \\
-0.0244 \\
-0.0121 \\
-0.0541 \\
-0.0844 \\
-0.0326 \\
-0.0135 \\
-0.0136 \\
0.0761\end{array}$ & $\begin{array}{r}1.0 \\
-0.12 \\
0.0 \\
0.0 \\
-0.0 \\
-0.0 \\
-0.0 \\
0.0 \\
0.0 \\
0.1 \\
0.2 \\
0.02\end{array}$ & $\begin{array}{l}00 \\
00 \\
81 \\
67 \\
41 \\
68 \\
78 \\
27 \\
41 \\
59 \\
82 * \star \\
29\end{array}$ & $\begin{array}{c}1.0000 \\
-0.1841 * \\
0.2533^{\star} \\
-0.0721 \\
0.2234^{\star} \\
-0.1200 \\
-0.1413 \\
0.0241 \\
-0.0061 \\
-0.0156 \\
-0.0143\end{array}$ & $\begin{array}{c}1.0000 \\
-0.1377 \\
-0.0830 \\
-0.0411 \\
-0.0912 \\
0.1933 * \\
-0.1108 \\
-0.0819 \\
-0.0453 \\
0.0534\end{array}$ & $\begin{array}{r}1.0000 \\
-0.0541 \\
-0.0268 \\
-0.1200 \\
-0.1873^{\star} \\
-0.0722 \\
0.0418 \\
-0.0223 \\
-0.0052\end{array}$ & $\begin{array}{r}1.0000 \\
0.4955 \\
-0.0541 \\
-0.0844 \\
0.1628^{\star} \\
0.0835 \\
-0.0093 \\
-0.4008 *\end{array}$ & $\begin{array}{r}1.0000 \\
-0.0268 \\
-0.0418 \\
0.3711^{\star} \\
-0.0067 \\
-0.0060 \\
-0.0081\end{array}$ \\
\hline 1 & 16 & 17 & 18 & 19 & 20 & 21 & & & \\
\hline $\begin{array}{l}\text { 16. Labor } \\
\text { 17. Religious } \\
\text { 18. Gender } \\
\text { 19. Log Employ } \\
\text { 20.Cash } \\
\text { 21. Mark.2Book }\end{array}$ & $\begin{array}{c}1.0000 \\
0.1873^{*} \\
-0.0722 \\
0.1614^{\star} \\
-0.0273 \\
0.1389\end{array}$ & $\begin{array}{r}1.0000 \\
-0.1127 \\
-0.0998 \\
0.1449 \\
0.0289\end{array}$ & $\begin{array}{r}1.0000 \\
-0.1362 \\
-0.0167 \\
-0.0292\end{array}$ & $\begin{array}{l}1.00 \\
0.05 \\
0.11\end{array}$ & $\begin{array}{rr}000 & \\
527 & 1.000 \\
192 & -0.007\end{array}$ & 1.000 & & & \\
\hline
\end{tabular}


$\underline{\text { Table } 2}$

Probit Estimates for First-Stage Boycott Target Model

Variables

Constant

Boycotts of Firm in Past Year

Boycotts of Industry in Past Year

Logged Total Assets

Base CSA Activity (^1/2)

other PR Activity (^1/2)

Observations

Log Pseudo-Likelihood

Fixed Effects for year included in the model but not recorded here.

$\star \mathrm{p}<0.05, * \star \mathrm{p}<0.01, * \star \star \mathrm{p}<0.001$

\section{Coefficients}

$-0.658 *$

$0.422 * \star \star$

$0.0689 *$

$-0.102 * \star$

$0.581 * \star \star$

0.0233

652

$-716.82$

Robust Standard Error

0.31

0.095

0.028

0.035

0.069

0.014 
Table 3:_Coefficients from the Second Stage in the Heckman Regression of the Change in the Number of Publicized Social Activities of Boycotted Firms, 1990-2005

\begin{tabular}{|c|c|c|c|c|}
\hline & Model 1 & Model 2 & Model 3 & Model 4 \\
\hline \multicolumn{5}{|c|}{ Independent Variables } \\
\hline \multirow[t]{2}{*}{ Reputation } & -0.255 & $-1.694 \star \star \star$ & -0.302 & $-1.582 * \star \star$ \\
\hline & $(0.45)$ & $(0.46)$ & $(0.51)$ & $(0.44)$ \\
\hline \multirow[t]{2}{*}{ Baseline CSA } & -1.079 & $-2.594 \star \star \star$ & -1.084 & $-2.353 * \star \star$ \\
\hline & $(0.78)$ & $(0.76)$ & $(0.87)$ & $(0.71)$ \\
\hline Reputation & & $0.980 \star \star$ & & $0.920 \star \star$ \\
\hline \multicolumn{2}{|l|}{ x Baseline CSA } & $(0.35)$ & & $(0.36)$ \\
\hline \multirow[t]{2}{*}{ Reputation Change } & 0.0766 & 0.191 & $0.946 *$ & $0.923 *$ \\
\hline & $(0.35)$ & $(0.35)$ & $(0.46)$ & $(0.45)$ \\
\hline \multirow[t]{2}{*}{ Media Attention } & $0.346 \star$ & 0.284 * & $0.280 * *$ & $0.236 *$ \\
\hline & $(0.15)$ & $(0.13)$ & $(0.099)$ & $(0.11)$ \\
\hline \multirow{2}{*}{\multicolumn{2}{|c|}{$\begin{array}{l}\text { Media x Reputation } \\
\text { Change }\end{array}$}} & & $1.338 * \star \star$ & $1.184 \star \star$ \\
\hline & & & $(0.39)$ & $(0.39)$ \\
\hline \multicolumn{5}{|l|}{ Controls } \\
\hline \multirow[t]{2}{*}{ Total Other PR } & 0.0692 & 0.0951 & 0.0906 & 0.103 \\
\hline & $(0.11)$ & $(0.099)$ & $(0.11)$ & $(0.097)$ \\
\hline \multirow[t]{2}{*}{ Subsidiary } & -0.943 & $-1.131 \star$ & $-0.990 *$ & $-1.181 *$ \\
\hline & $(0.51)$ & $(0.50)$ & $(0.48)$ & $(0.51)$ \\
\hline \multirow[t]{2}{*}{ Ind. Technology } & $-3.405 \star \star$ & $-3.999 * \star \star$ & $-3.701 * \star \star$ & $-4.182 * \star \star$ \\
\hline & $(1.14)$ & $(1.16)$ & $(1.10)$ & $(1.15)$ \\
\hline \multirow{2}{*}{ Ind. Health } & 2.014 & $2.586 \star \star$ & 1.822 & $2.598 * \star$ \\
\hline & $(1.44)$ & $(0.96)$ & $(1.54)$ & $(1.01)$ \\
\hline \multirow[t]{2}{*}{ Ind. Finance } & 0.128 & -0.106 & 0.0392 & -0.366 \\
\hline & $(1.63)$ & $(1.21)$ & $(1.55)$ & $(1.11)$ \\
\hline \multirow[t]{2}{*}{ Ind. Media } & 0.170 & 0.274 & -0.0111 & 0.124 \\
\hline & $(0.63)$ & $(0.62)$ & $(0.60)$ & $(0.59)$ \\
\hline \multirow[t]{2}{*}{ Issue Environment } & 1.058 & 1.502 & 1.482 & 1.597 \\
\hline & $(1.13)$ & $(1.11)$ & $(1.35)$ & $(1.03)$ \\
\hline \multirow[t]{2}{*}{ Issue Safety } & 3.695 & 4.252 & $-9.301 *$ & -7.274 \\
\hline & $(3.06)$ & $(2.68)$ & $(4.23)$ & $(4.42)$ \\
\hline \multirow[t]{2}{*}{ Issue Labor } & 1.849 & 1.547 & 2.141 & 1.636 \\
\hline & $(1.21)$ & $(0.86)$ & $(1.75)$ & $(0.89)$ \\
\hline \multirow[t]{2}{*}{ Issue Animals } & -2.976 & -2.960 & $-5.521 *$ & $-5.036 *$ \\
\hline & $(2.62)$ & $(2.58)$ & $(2.65)$ & $(2.39)$ \\
\hline \multirow[t]{2}{*}{ Issue Religious } & -0.247 & -0.374 & -0.264 & -0.419 \\
\hline & $(0.49)$ & $(0.48)$ & $(0.60)$ & $(0.51)$ \\
\hline \multirow[t]{2}{*}{ Issue Gender } & $4.429 * \star \star$ & $4.638 \star \star \star$ & $4.155 * \star \star$ & 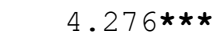 \\
\hline & $(1.26)$ & $(1.19)$ & $(1.17)$ & $(1.10)$ \\
\hline \multirow[t]{2}{*}{ Log Employees } & 0.457 & $0.544 *$ & 0.438 & $0.478 *$ \\
\hline & $(0.28)$ & $(0.23)$ & $(0.31)$ & $(0.22)$ \\
\hline Cash & $0.00531 * \star \star$ & $0.00631 * \star \star$ & $0.00510 * \star$ & $0.00581 * \star \star$ \\
\hline & $(0.0015)$ & $(0.0012)$ & $(0.0016)$ & $(0.0013)$ \\
\hline Market to Book & $-0.0745 \star$ & $-0.0847 \star \star \star$ & $-0.0850 *$ & $-0.0878 * \star \star$ \\
\hline Ratio & $(0.030)$ & $(0.023)$ & $(0.042)$ & $(0.022)$ \\
\hline Selection & -1.62 & $-1.50 \star \star$ & -1.81 & $-1.43 \star \star$ \\
\hline Correction Effect & $(1.25)$ & $(0.51)$ & $(1.39)$ & $(0.49)$ \\
\hline Constant & 6.097 & $7.067 \star \star \star$ & $6.984 *$ & $7.263 \star \star \star *$ \\
\hline & $(3.74)$ & $(1.90)$ & $(3.37)$ & $(1.85)$ \\
\hline Observations & 165 & 165 & 165 & 165 \\
\hline
\end{tabular}

Robust standard errors are in parentheses

Fixed Effects for year included in the model but not recorded here.

$\star \mathrm{p}<0.05, * \star \mathrm{p}<0.01, * \star \star \mathrm{p}<0.001$ 
Table 4: Coefficients for the Probit Regression of Post-boycott Reputational Decline on Independent Variables

\begin{tabular}{|l|c|c|}
\hline Variable & Coefficient & Standard error \\
\hline Change in CSA count & $-.10^{* *}$ & .03 \\
\hline Reputation (original) & $1.51^{* * *}$ & .23 \\
\hline Baseline CSA & .23 & .16 \\
\hline Past reputational change & -.07 & .32 \\
\hline Media attention & $.32^{*}$ & .13 \\
\hline Other PR (total) & .0003 & .0005 \\
\hline Subsidiary & -.46 & .29 \\
\hline Ind. Technology & -.43 & .44 \\
\hline Ind. Health & $2.55^{* * *}$ & .93 \\
\hline Ind. Finance & .35 & .36 \\
\hline Ind. Media & -.62 & .58 \\
\hline Issue - Environment & $1.25^{*}$ & .62 \\
\hline Issue - Labor & .66 & .47 \\
\hline Issue - Morality & -.59 & .38 \\
\hline Log of employees & -.06 & .09 \\
\hline Free cash flow & $-.09^{*}$ & .04 \\
\hline Market to book ratio & $-.08^{\dagger}$ & .05 \\
\hline Constant & $-1.79^{* *}$ & .67 \\
\hline Observations & 162 & \\
\hline Log likelihood & -48.36 & \\
\hline
\end{tabular}

$\dagger \mathrm{p}<.10, * \mathrm{p}<0.05, * * \mathrm{p}<0.01, * * * \mathrm{p}<0.001$, 


\section{$\underline{\text { References }}$}

\section{Aguilera, R.V., D.E. Rupp, C.A. Williams, and J. Ganapathi}

2007. "Putting the $\mathrm{S}$ back in corporate social responsibility: A multilevel theory of social change in organizations." Academy of Management Review, 32: 836-863.

\section{Armstrong, E.}

2002. Forging gay identities: Organizing sexuality in San Francisco, 1950-1994. Chicago, IL: University of Chicago Press.

\section{Baron, D.P.}

1999. "Integrated market and non-market strategies in client and interest group politics." Business and Politics, 1:7-34.

\section{Baron, D.P.}

2001. "Private politics, corporate social responsibility, and integrated strategy." Journal of Economics and Management Strategy, 10: 7-45.

\section{Bartley, T.}

2003. "Forests and factories: States, social movements, and the rise of private regulation in the apparel and forest products fields." Politics \& Society, 31: 433-464.

\section{Bartley, T.}

2007. "Institutional emergence in an era of globalization: The rise of transnational private regulation of labor and environmental conditions." American Journal of Sociology, 113: 297-351.

\section{Bartley, T. and C. Child}

2010. "Shaming the corporation: globalization, reputation, and the dynamics of anti-corporate movements." (Working Paper).

\section{Bernstein, D.}

1984. Company image and reality: A critique of corporate communications. Eastbourne, UK: Holt, Rinehart \& Winston.

\section{Bernstein, M.}

2005. "Identity politics." Annual Review of Sociology, 31: 47-74.

\section{Bromley, D.B.}

1993. Reputation, Image, and Impression Management. Chichester, UK: Wiley.

\section{Burt, R.}

1983. "Corporate philanthropy as a cooptive relation." Social Forces, 62: 419-449. 


\section{Carmeli, A., G. Gershon, and A.W. David}

2007. "The role of perceived organizational performance in organizational identification, adjustment and job performance.” Journal of Management Studies, 44: 972-992.

\section{Carroll, A.B.}

1989. Business and Society: Ethics and Stakeholder Management. Cincinnati, OH: SouthWestern.

\section{Chen, S. and P. Bouvain}

2009. "Is Corporate Responsibility Converging? A comparison of corporate responsibility reporting in the USA, UK, Australia, and Germany." Journal of Business Ethics, 87: 299-317.

\section{Clarkson, M.B.E.}

1995. "A stakeholder framework for analyzing and evaluating corporate social responsibility." Academy of Management Review, 20: 92-117.

\section{Clemens, E.S.}

1997. The People's Lobby: Organizational Innovation and the Rise of Interest Group Politics in the United States, 1890-1925. Chicago, IL: University of Chicago Press.

\section{Coombs, W.T. and S.J. Halladay}

2006. "Unpacking the halo effect: Reputation and crisis management." Journal of Communication Management, 10:123-138.

\section{Cress, D.M. and D.A. Snow}

2000. "The outcomes of homeless mobilization: The influence of organization, disruption, political mediation, and framing." American Journal of Sociology, 105: 1063-1104.

\section{Dacin, M.T.}

1997. "Isomorphism in Context: The power and prescription of institutional norms." Academy of Management Journal, 40:46-81.

Davis, $\mathbf{K}$.

1973. "The case for and against business assumption of social responsibilities." Academy of Management Journal, 16: 312-322.

Davis, G.F. and S.K. Stout

1992. "Organization theory and the market for corporate control: A dynamic analysis of the characteristics of large takeover targets, 1980-1990." Administrative Science Quarterly, 37: 605-633.

Davis, G.F., M. von Neumann Whitman, and M.N. Zald

2008. "The responsibility paradox." Stanford Social Innovation Review, Winter: 30-37. 


\section{Delmas, M. and M.W. Toffel}

2004. "Stakeholders and environmental management practices: An institutional framework." Business Strategy and the Environment, 13: 209-222.

\section{Deng, $\mathbf{F}$.}

1997. "Information gaps and the unintended outcomes of social movements: The 1989 Chinese student movement.” American Journal of Sociology, 102: 1085-1112.

\section{Dimaggio, P.J. and W.W. Powell}

1983. "The iron cage revisited: institutional isomorphism and collective rationality in organizational fields.” American Sociological Review, 48: 147-160.

\section{Dowling, J. and J. Pfeffer}

1975. "Organizational legitimacy: Social values and organizational behavior." The Pacific Sociological Review, 18: 122.

\section{Dutton, J.E. and J.M. Dukerich}

1991. "Keeping an eye on the mirror: Image and identity in organizational adaptation." Academy of Management Journal, 34: 517-554.

\section{Dutton, J.E., J.M. Dukerich, and C.V. Harquail}

1994. "Organizational images and member identification.” Administrative Science Quarterly, 39: 239-263.

\section{Earl, J.}

2000. "Methods, movements, and outcomes: Methodological difficulties in the study of extramovement outcomes." Research in Social Movements, Conflicts, and Change, 22 :3-25.

Earl, J., S.A. Soule and J.D. McCarthy

2003. "Protest under fire? Explaining the policing of protest." American Sociological Review, 68: 581-606.

\section{Earl, J., A. Martin, S.A. Soule and J.D. McCarthy}

2004. "The use of newspaper data in the study of collective action." American Review of Sociology, 30: 65-80.

Elsbach, K.D., and Roderick M. Kramer.

1996. "Members' Responses to Organizational Identity threats: Encountering and countering the Business Week rankings.” Administrative Science Quarterly, 41:442-476.

\section{Elsbach, K. D., and R. I. Sutton}

1992 "Acquiring organizational legitimacy through illegitimate actions - a marriage of institutional and impression management theories." Academy of Management Journal, 35: 699-738. 
Fine, G.A.

1996. "Reputational Entrepreneurs and the Memory of Incompetence: Melting Supporters, Partisan Warriors, and Images of President Harding." American Journal of Sociology, 101: 1159-83.

\section{Fombrun, C.J.}

1996. Reputation: Realizing Value from the Corporate Image. Boston, MA: Harvard Business School Press.

\section{Fombrun, C.J. and M. Shanley}

1990. "What's in a Name? Reputation Building and Corporate Strategy." Academy of Management Journal, 33:233-258.

Freeman, R.E. and D.R. Gilbert, Jr.

1987. "Managing stakeholder relationships." In S.P. Sethi \& C.M. Falbe (Eds.), Business and Society: 397-423. Lexington, MA: Lexington.

\section{Friedman, M.}

1985. Consumer Boycotts: Effecting Change through the Marketplace and Media. New York, NY: Routledge.

\section{Gardberg, N.A. and W. Newburry}

2010. "Who Boycotts Whom?Marginalization, Company Knowledge and Strategic Issues." Business and Society.

\section{Gioia, D.A., M. Schultz, and K.G. Corley}

2000. "Organizational Identity, Image, and Adaptive Instability." The Academy of Management Review, 25: 63-81.

\section{Giugni, M.}

1998. "Was it worth the effort? The outcomes and consequences of social movements." Annual Review of Sociology, 24: 371-393.

Giugni, M., D. McAdam, and C. Tilly

1999. How social movements matter. Minneapolis, MN: University of Minnesota Press.

\section{Godfrey, P.C.}

2005. "The relationship between corporate philanthropy and shareholder wealth: A risk management perspective." Academy of Management Review, 30: 777-798.

\section{Godfrey, P.C., C.B. Merrill and J.M. Hansen}

2009. "The relationship between corporate social responsibility and shareholder value: An empirical test of the risk management hypothesis." Strategic Management Journal, 30: 425-445. 
Goffman, E.

1959. The Presentation of Self in Everyday Life. New York, NY: Doubleday.

Gray, R., R. Kouhy, and S. Lavers

1995. "Corporate social and environmental reporting: A review of the literature and a longitudinal study of UK disclosure." Accounting, Auditing and Accountability Journal, $8: 47-77$.

Hannan, M.T., L. Pólos and G.R.Carroll

2007. Logics of Organization Theory: Audiences, Codes and Ecologies. Princeton, NJ: Princeton University Press.

Haveman, H., H. Rao and S. Paruchuri

2007. "The winds of change: The progressive movement and the bureaucratization of thrift." American Sociological Review, 72:114-142.

Hiatt, S.R., W.D. Sine, and P. Tolbert

2009. "From Pabst to Pepsi: The deinstitutionalization of social practices and the creation of entrepreneurial opportunities.” Administrative Science Quarterly, 54: 635-667.

Hoffman, A.J. and W. Ocasio

2001. "Not all events are attended equally: Toward a middle-range theory of industry attention to external events." Organization Science, 12: 415-434.

Holder-Webb, L., J.R. Cohen, L. Nath and D. Wood

2009. "The supply of corporate social responsibility disclosures among U.S. firms." Journal of Business Ethics, 84: 497-527.

Hsu, G.

2006. "Jacks of all trades and masters of none: Audiences' reactions to spanning genres in feature film production.” Administrative Science Quarterly, 51: 420-450.

Hsu, G. and M.T. Hannan

2005. "Identities, genres and organizational forms." Organization Science, 16: 474-490.

Hsu, G., M.T. Hannan, and Ö. Koçak

2009. "Multiple category memberships in markets: A formal theory and two empirical tests." American Sociological Review, 74: 150-169.

Ingram, P., L. Qingyuan Yue and H. Rao

2010. "Trouble in store: Probes, protests and store openings by Wal-Mart: 1998-2005." American Journal of Sociology, 116; 53-92.

King, B.G.

2008. "A Political Mediation Model of Corporate Response to Social Movement Activism." Administrative Science Quarterly, 53:395-421. 
King, B.G. and S.A. Soule

2007. "Social movements as extra-institutional entrepreneurs: The effect of protests on stock price returns." Administrative Science Quarterly, 52: 413-442.

King, B.G. and D.A. Whetten

2008. "A social identity formulation of organizational reputation and legitimacy." Corporate Reputation Review, 11: 192-207.

King, B.G., T. Felin, and D.A. Whetten

2009. "Finding the organization in organizational theory: A meta-theory of the organization as a social actor." Organization Science, 21: 290-305.

Koopmans, R. and S. Olzak

2004. "Discursive Opportunities and the Evolution of Right-Wing Violence in Germany." American Journal of Sociology, 110: 198-230.

\section{Lipsky, M.}

1968. "Protest as a political resource." American Political Science Review, 62: 1144-1158.

\section{Lounsbury, $M$.}

2001. "Institutional sources of practice variation: Staffing college and university recycling programs." Administrative Science Quarterly, 46: 29-56.

\section{Love, E.G. and M. Kraatz}

2009. "Character, conformity, or the bottom line: How and why downsizing affected corporate reputation." Academy of Management Journal, 52: 314-335.

\section{Luders, J.E.}

2006. "The economics of success: Business responses to civil rights mobilization." American Journal of Sociology, 111: 963-998.

Mackey, A., T.B. Mackey, and J.B. Barney

2007. "Corporate Social Responsibility and firm performance: Investor preferences and corporate strategies." Academy of Management Review, 32: 817-835.

\section{Marquis, C., M.A. Glynn, and G.F. Davis}

2007. "Community isomorphism and corporate social action." Academy of Management Review, 32: 925-945.

\section{Marshall, R.S., M. Cordano, and M. Silverman}

2005. "Exploring individual and institutional drivers of proactive environmentalism in the US wine industry." Business Strategy and the Environment, 14: 92-109.

Maxwell, J.W., T.P. Lyon, and S.C. Hackett

2000. "Self-regulation and social welfare: The political economy of corporate environmentalism." Journal of Law and Economics, 43: 583-617. 
McAdam, D.

1983. "Tactical Innovation and the Pace of Insurgency." American Sociological Review, 48: 735-754.

McAdam, D. and W.R. Scott

2005. "Organizations and movements.” In G.F. Davis, D. McAdam, W.R. Scott \& M.N. Zald (eds.) Social Movements and Organization Theory: 4-40. New York, NY: Cambridge Univ. Press.

McAdam, D. and Y. Su

2002. "The war at home: Antiwar protests and congressional voting, 1665 to 1973." American Sociological Review, 67: 696-721.

McAdam, D., S. Tarrow and C. Tilley

2001. Dynamics of Contention. Cambridge, UK: Cambridge University Press.

McCammon, H.J., K.E. Campbell, E.M. Granberg, and C. Mowery

2001. "How movements win: Gendered opportunity structures and U.S. women's suffrage movements, 1965-1973.” American Sociological Review, 66: 49-70.

McGuire, J.B., A. Sundgren, and T. Schneeweis

1988. "Corporate social responsibility and firm financial performance." Academy of Management Journal, 31: 854-872.

Meyer, J.W. and B. Rowan

1977. "Institutional organizations: Formal structure as myth and ceremony." American Journal of Sociology, 83: 440-463.

Miller, K.E. and F.D. Sturdivant

1977. "Consumer responses to socially questionable corporate behavior: An empirical test." Journal of Consumer Research, 4: 1-7.

Montgomery, D.B. and C.A. Ramus

2010. "Challenging work and corporate responsibility will lure MBA grads." Working Paper.

Oberschall, A.

1973. Social conflict and social movements. Englewood Cliffs, NJ: Prentice-Hall.

Ocasio, W.

1997. "Towards an attention-based view of the firm." Strategic Management Journal, 18:187206.

Ocasio, W.

2001. "Not all events are attended equally: Toward a middle-range theory of industry attention to external events." Organization Science, 12: 414-434. 
Oliver, C.

1991. "Strategic responses to institutional processes." Academy of Management Review, 16: 145-179.

Oliver, C.

1997. "Sustainable competitive advantage: Combining institutional and resource-based views." Strategic Management Journal, 18: 697-713.

Olzak, S. and S.C.N. Uhrig

2001. "The ecology of tactical overlap." American Sociological Review, 66: 694-717.

Parsons, T.

1960. Structure and process in modern societies. Glencoe, IL: Free Press.

Piven, F.F. and R. Cloward

1977. Poor People's Movements: Why They Succeed, How They Fail. New York, NY: Pantheon Books.

Price, K.N., D.A. Gioia, and K.G. Corley

2008. "Reconciling Scattered Images: Managing disparate organizational expressions and impressions.” Journal of Management Inquiry, 17: 173-185.

Pruitt, S.W. and M. Friedman

1986. "Determining the effectiveness of consumer boycotts: A stock price analysis of their impact on corporate targets." Journal of Consumer Policy, 9: 375-387.

Pruitt, S.W., K.C.J. Wei, and R.E. White

1988. "The impact of union-sponsored boycotts on stock prices of target firms." The Journal of Labor Research, IX: 285-289.

Raeburn, N.C.

2004. Changing corporate America from the inside out: Lesbian and gay workplace rights. Minneapolis, MN: Univ. of Minnesota Press.

Rao, H., C. Morrill, and M. Zald

2000. "Power plays: Social movements, collective action, and new organizational forms." Research in Organizational Behavior, 22: 237-281.

Reid, E. M., and M. W. Toffel

2009. "Responding to Public and Private Politics: Corporate Disclosure of Climate Change Strategies." Strategic Management Journal, 30: 1157-1178.

Rindova, V.P. and C.J. Fombrun

1999. "Constructing competitive advantage: The role of firm-constituent interactions." Strategic Management Journal, 20: 691-710. 
Rivera, L.A.

2008. "Managing 'spoiled' national identity: War, tourism, and memory in Croatia." American Sociological Review, 73: 613-634.

\section{Roberts, P.W. and G.R. Dowling}

2002. "Corporate reputation and sustained superior financial performance." Strategic Management Journal, 23: 1077-1093.

Rojas, F.

2006. "Social movement tactics, organizational change, and the spread of African-American studies." Social Forces, 84: 2147-2166.

\section{Scherer, A.G. and G. Palazzo}

2007. "Toward a political conception of corporate responsibility: Business and society seen from a Habermasian perspective." Academy of Management Review, 32: 1096-1120.

\section{Schurman, R. and W. Munro}

2009. "Targeting capital: a cultural economy approach to understanding the efficacy of two antigenetic engineering movements." American Journal of Sociology, 115: 155-202.

\section{Scott, W. R.}

1995. Institutions and Organizations. Thousand Oaks, CA: Sage.

\section{Scott, W.R., M. Ruef, P.J. Mendel, and C.A. Caronna}

2000. Institutional Change and Healthcare Organizations. Chicago, IL: Univ. Chicago Press.

\section{Selznick, $\mathbf{P}$.}

1957. Leadership in Administration: A Sociological Interpretation. Evanston, IL: Row, Peterson.

\section{Selznick, P.}

1996. 'Institutionalism ‘old' and 'new'.” Administrative Science Quarterly, 41: 270-277.

\section{Simon, H.A.}

1947. Administrative Behavior: A Study of Decision-making Processes in Administrative Organizations. Chicago, IL: Macmillan.

\section{Sine, W.D., S. Shane, and D. Di Gregorio}

2003. "The halo effect and technology licensing: The influence of institutional prestige on the licensing of university inventions." Management Science 49: 478-497.

Sine, W.D. and B.H. Lee

2009. "Tilting at windmills? The environmental movement and the emergence of the U.S. wind energy sector." Administrative Science Quarterly, 123-155. 


\section{Skrentny, J.D.}

2006. "Policy-elite perceptions and social movement success: Understanding variations in group inclusion in affirmative action." American Journal of Sociology, 111: 1762-1815.

Soule, S.A.

2009. Contention and Corporate Social Responsibility. New York, NY: Cambridge University Press.

Soule, S.A. and S. Olzak

2004. "When do movements matter? The politics of contingency and the equal rights amendment." American Sociological Review, 69: 473-497.

\section{Soule, S.A. and B.G. King}

2006. "The impact of social movements at stages of the policy process: The equal rights amendment, 1972-1982.” American Journal of Sociology, 111: 1871-1909.

\section{Soule, S.A., D. McAdam, J. McCarthy, and Y. Su}

1999. "Protest events: Cause or consequence of state action? The U.S. women's movement and federal congressional activities, 1956-1979." Mobilization, 4: 223-238.

\section{Staw, B.M. and L.D. Epstein}

2000. "What bandwagons bring: Effects of popular management techniques on corporate performance, reputation, and CEO pay.” Administrative Science Quarterly, 45: 523-556.

\section{Strang, D. and S.A. Soule}

1998. "Diffusion in organizations and social movements: From hybrid corn to poison pills." Annual Review of Sociology, 24: 265-290.

\section{Useem, M.}

1984. The Inner Circle: Large Corporations and the Rise of Business Political Activity in the U.S. and U.K. London, UK: Oxford University Press.

Van Dyke, N., S.A. Soule, and V.A. Taylor

2004. "The targets of social movements: Beyond a focus on the state." Research in social movements, conflicts, and change, 25: 27-51.

\section{Vogel, D.}

2005. The Market for Virtue: The Potential and Limits of Corporate Social Responsibility. Washington, DC: Brookings.

\section{Waddock, S.A.}

2004. "Parallel universes: Companies, academics, and the progress of corporate citizenship." Business and Society Review, 109: 5-42. 


\section{Waddock, Sandra A. and Samuel B. Graves}

1997. "The corporate social performance-financial performance link." Strategic Management Journal, 18: 303-319.

Walgrave, S. and J. Manssens

2000. "The making of the white march: The mass media as a mobilizing alternative to movement organizations.” Mobilization: An International Quarterly, 5: 217-239.

Walsh, J.P., K. Weber, and J.D. Margolis

2003. "Social issues and management: Our lost cause found." Journal of Management, 29: 859881.

Weber, K., K.L. Heinze, and M. deSoucey

2008. "Forage for thought: Mobilizing codes in the movement for grass-fed meat and dairy products.” Administrative Science Quarterly, 53: 529-567.

Weber, K., H. Rao, and L.G. Thomas

2009. "From streets to suites: how the anti-biotech movement affected German pharmaceutical firms." American Sociological Review, 74: 106-27.

Whetten, D.A. and A. Mackey

2002. "A social actor conception of organizational identity and its implications for the study of organizational reputation." Business and Society, 41: 393-414.

Whetten, D.A.

2006. "Albert and Whetten revisited: Strengthening the concept of organizational identity." Journal of Management Inquiry, 15: 219-234.

\section{Weigelt, K. and C. Camerer}

1988. "Reputation and corporate-strategy - A review of recent theory and applications." Strategic Management Journal, 9: 443-454.

Wood, D.J.

1991a. "Corporate social performance revisited." Academy of Management Review, 16: 691718.

Wood, D.J.

1991b. "Social issues in management: Theory and research in corporate social performance." Journal of Management, 17: 383-406.

\section{Wood, D.J. and R.E. Jones}

1995. "Stakeholder mismatching: A theoretical problem in empirical research on corporate social performance." International Journal of Organizational Analysis, 3: 229-267. 


\section{Zuckerman, E.W.}

1999. "The categorical imperative: Securities analysts and the illegitimacy discount." American Journal of Sociology 104: 1398-1438. 